\title{
The Discovery and Development of Daclatasvir: An Inhibitor of the Hepatitis C Virus NS5A Replication Complex
}

\author{
Nicholas A. Meanwell and Makonen Belema
}

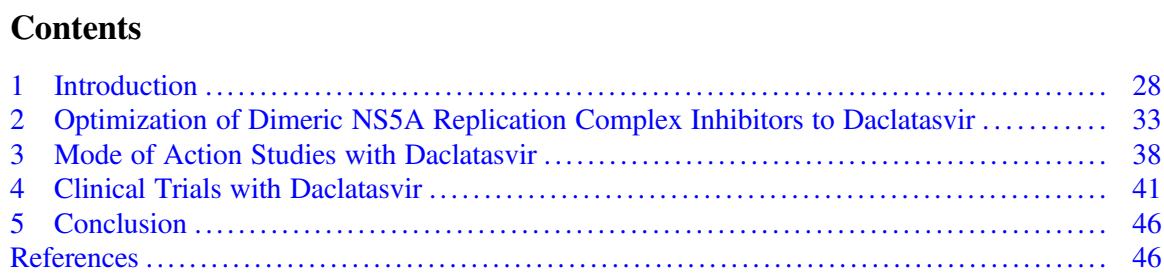

\begin{abstract}
The discovery of the hepatitis $\mathrm{C}$ virus (HCV) NS5A replication inhibitor daclatasvir (1) had its origins in a phenotypic screening lead. However, during the optimization campaign, it was observed that some members of the chemotype underwent a radical dimerization under the assay conditions. This redirected the effort to focus on palindromic molecules, a species subsequently shown to complement the dimeric nature of the NS5A protein. The most challenging aspect of the discovery program was extending antiviral activity to encompass GT-1a virus which was accomplished only after the development of extensive structure-activity relationships. In clinical trials, oral administration of daclatasvir (1) produced a profound effect on viral load with onset that was more rapid than had been seen previously with either NS3 protease or NS5B polymerase inhibitors. A groundbreaking clinical trial that combined daclatasvir (1) with the protease inhibitor asunaprevir (52) established that a chronic HCV infection could be cured with small molecule therapy in the absence of immune stimulation, setting the stage for approval of this regimen for the treatment of GT-1b-infected subjects by the Japanese health authorities on July 4, 2014.
\end{abstract}

\author{
N. A. Meanwell ( $\square)$ \\ Department of Discovery Chemistry, Bristol-Myers Squibb Research and Development, \\ Princeton, NJ, USA \\ e-mail: Nicholas.meanwell@bms.com

\section{Belema} \\ Department of Discovery Chemistry and Molecular Technologies, Bristol-Myers Squibb \\ Research and Development, Princeton, NJ, USA \\ e-mail: Makonen.belema@bms.com
}


Keywords Asunaprevir, Beclabuvir, Daclatasvir, Dimerization, Hepatitis C virus, NS5A inhibitor, NS3 protease inhibitor, Sofosbuvir, Synergy

\section{Introduction}

The discovery of the hepatitis $\mathrm{C}$ virus (HCV) nonstructural 5A (NS5A) replication complex inhibitor daclatasvir (1) began with the development of a genotype $1 \mathrm{~b}$ (GT-1b) replicon that was implemented as a phenotypic screen using a design that conferred a stringent triaging of hit molecules [1-11]. This screening campaign was part of a broader strategy that pursued the identification of mechanistically orthogonal inhibitors of HCV that could be used in combination therapy, an approach that anticipated clinical use of drug cocktails to minimize the selection of resistant viruses. More specifically, the replicon screen comprised of simultaneously assessing the antiviral activity of test molecules toward a sub-genomic HCV GT-1b construct and a bovine viral diarrhea virus (BVDV) replicon, both replicating in the same human liver Huh-7 cell line background and seeded in the same well of a 96-well plate [6]. HCV inhibition was determined indirectly using a fluorescence resonance energy transfer (FRET)-based assay that assessed NS3 protease activity toward a synthetic substrate incorporating both a fluorescence donor [(5-((2-aminoethyl)amino)naphthalene-1-sulfonic acid (EDANS)] in the amino terminus and a fluorescence acceptor [4-((4-(dimethylamino)phenyl)azo)benzoic acid, succinimidyl ester (DABCYL)] at the carboxyl terminus. The BVDV replicon incorporated a firefly luciferase reporter gene that provided an orthogonal readout of replication activity based on the emission of light, reflecting the amount of enzyme present after adding a substrate. The third piece of information harvested from the assay, which was also the first experimental data obtained, was AlamarBlue cell viability staining which assessed mitochondrial function, providing an indication of the cytotoxicity of test compounds. This assay configuration was used to interrogate a representative selection of the Bristol-Myers Squibb proprietary compound collection and identified the iminothiazolidinone $\mathbf{2}$ as hit that met the criteria of exhibiting activity toward the HCV replicon at concentrations at least tenfold lower than either inhibitory activity toward the BVDV replicon or cytotoxicity [12]. The specific details of the antiviral profile of $\mathbf{2}$ in the screening assays and toward a panel of viruses are summarized in Table 1. Compound $\mathbf{2}$ had an interesting background since it had its origin in a prospective library that had been prepared as part of a campaign to embellish the Bristol-Myers Squibb proprietary compound collection. A notable structural feature of $\mathbf{2}$ is that it had been designed to include a phenyl substituent at C-5, unusual since C-5 benzylidene derivatives are far more prevalent in the literature, a function of convenient access by way of a Knoevenagel condensation reaction between a C-5 unsubstituted iminothiazolidinone and an aldehyde $[13,14]$. 
Table 1 Antiviral activity of 2 in the GT-1b HCV replicon and toward a panel of viruses

\begin{tabular}{l|l|c}
\hline Assay & $\mathrm{EC}_{50}(\mu \mathrm{M})$ & $\mathrm{CC}_{50}(\mu \mathrm{M})$ \\
\hline GT-1b HCV replicon & 0.57 & $>50$ \\
\hline BVDV replicon & 24 & $>100$ \\
\hline BVDV virus & 17 & $>150$ \\
\hline HIV-1 & 41 & 41 \\
\hline HRV & $>100$ & $>100$ \\
\hline RSV & 23 & 23 \\
\hline
\end{tabular}

$H I V-1$ human immunodeficiency virus-1, HRV human rhinovirus, $R S V$ respiratory syncytial virus
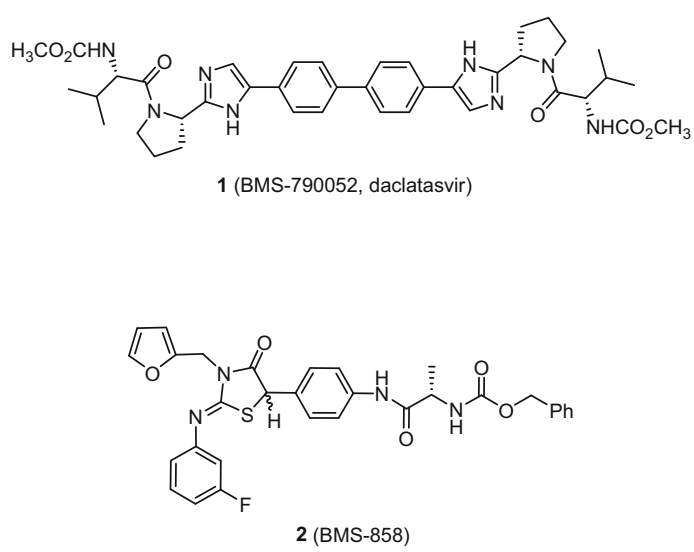

The data accumulated for 2 that are compiled in Table 1 revealed a profile of significant and selective inhibitory potency toward the GT-1b HCV replicon with an $\mathrm{EC}_{50}$ value of $570 \mathrm{nM}$, a finding that encouraged further study of the chemotype [15]. Adding to the intrigue with $\mathbf{2}$ as a lead inhibitor was the generation and validation of resistant mutants arising in the replicon in response to selective pressure that mapped to the amino terminus of the NS5A protein, specifically a Tyr98His and a Leu31 Val/Gln54Leu combination [12]. At the time of this discovery, little was known about the specific functions of the NS5A protein in viral replication although, perhaps not surprisingly for such a small virus, it was known to be an essential protein [16-20].

The Z-configuration of the 2-arylimino moiety of $\mathbf{2}$ was assigned based on prior studies which indicated that this topology minimized steric effects. However, attempts to separate the individual stereoisomers at C-5 were thwarted by facile racemization of the benzylic center after chiral chromatographic separation $[15,21]$. Seminal insights into structure-activity relationships (SARs) were gleaned from a survey that explored variation of the three major peripheral elements of the molecule - the furanylmethyl substituent, the arylimino moiety, and the amino acid amide. Changes to both the furanylmethyl and arylimino moieties in the context of the Cbz-alanine amide were found to influence potency, with compounds incorporating polar heterocycles being the more potent, while more lipophilic substituents 
generally exhibited poorer replicon inhibitory activity. Overall, a good dynamic range of potency was observed with the structural variations sampled, with $\mathrm{EC}_{50}$ values ranging from 10 to $2.5 \mu \mathrm{M}$. However, more profound and precise effects on HCV GT-1b inhibitory potency were associated with changes to the Cbz-alanine amide element, with the key findings summarized in Fig. 1. The unnatural alanine analogue 3 was 170-fold less potent, while the glycine homologue 4 was eightfold weaker than $\mathbf{2}$. The strong dependence of antiviral activity on the absolute configuration of the amino acid element was reproduced in the proline derivatives $\mathbf{5}$ and $\mathbf{6}$, both of which were fivefold more potent than their alanine congeners [15]. Replacing the Cbz element with a dihydrocinnamate moiety resulted in an erosion of potency in both series, as exemplified by $\mathbf{7}$ and $\mathbf{9}$. However, a significant increase in potency was observed with the phenylacetamide moiety found in $\mathbf{8}$ and $\mathbf{1 0}$, with both compounds expressing single digit nanomolar $\mathrm{EC}_{50}$ values in the replicon and confirming the inherent advantage offered by proline. Only weak antiviral effects were observed with the many other amino acids and additional structural variations that were explored at this site of the pharmacophore, with some representative examples of those sampled compiled in Fig. 2 [15].

While these collective SARs appeared to be coherent and were readily interpretable, as highlighted by the sensitivity of potency to changes to the amino acid element, as exploration of $\mathbf{2}$ and its analogues continued, it became apparent that the iminothiazolidinone chemotype was unstable under some conditions $[15,22]$. The first indication of a problem was the observation that a sample of 2 degraded upon standing as a solution in DMSO for several days, with the thiohydantoin $15\left(\mathrm{R}_{3}=\mathrm{NHCO}_{2} \mathrm{CH}_{2} \mathrm{Ph}\right)$ and thiourea $17\left(\mathrm{R}_{3}=\mathrm{NHCO}_{2} \mathrm{CH}_{2} \mathrm{Ph}\right)$ determined to be two of the degradation products after a preparative experiment (Scheme 1). In the replicon, 15 exhibited a modest inhibitory activity, $\mathrm{EC}_{50}=13 \mu \mathrm{M}$,
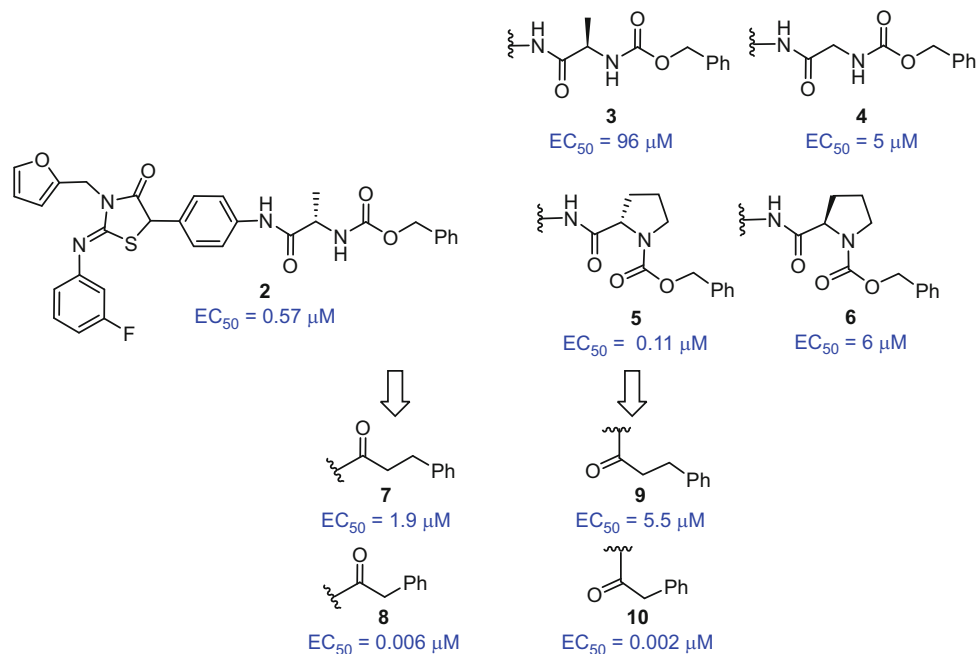

Fig. 1 Structure-activity relationships associated with variation of the amino acid moiety of 2 


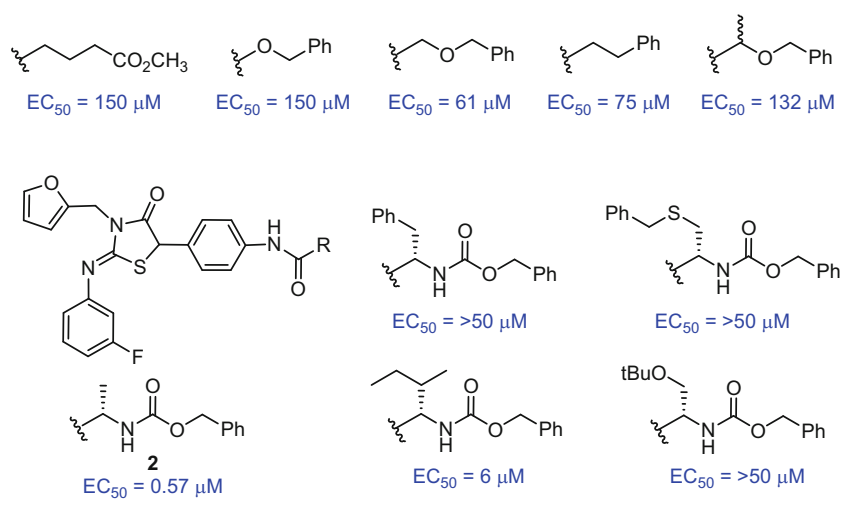

Fig. 2 Structure-activity relationships associated with the amino acid element of 2
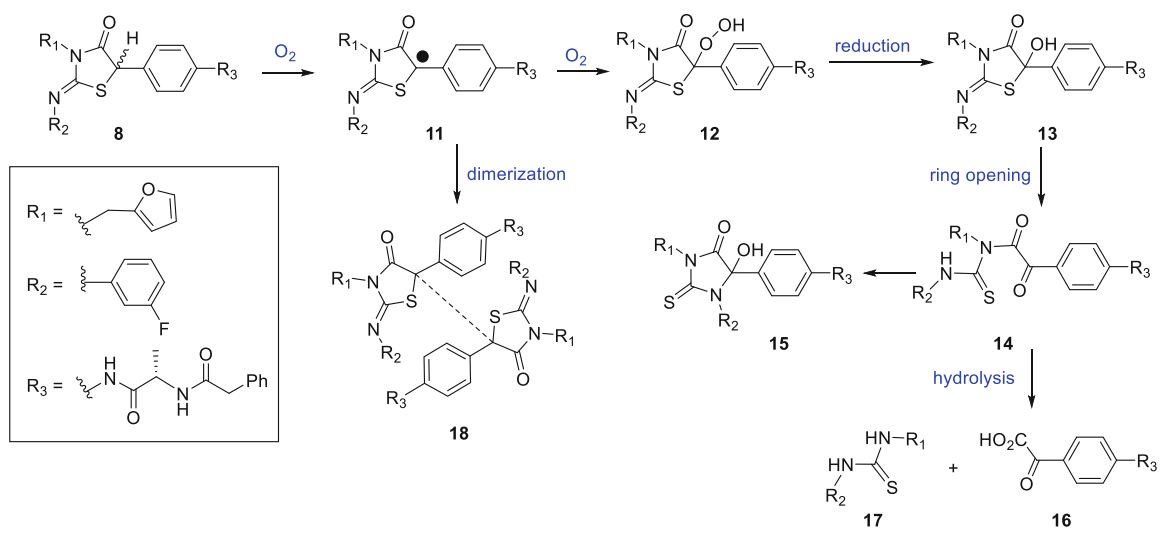

Scheme 1 Chemical degradation path elucidated for 2

while 17 was essentially inactive. Compounding the intrigue, incubating the more potent $\mathbf{8}$ in replicon media until degradation was complete and then assessing the antiviral activity of the preparation in the GT-1b replicon demonstrated that the HCV inhibitory activity and potency were fully preserved [15, 22]. A more detailed analysis of the degradation products from $\mathbf{8}$ guided by high-performance liquid chromatography (HPLC) biogram analysis, in which fractions taken from the chromatography column are concentrated and assessed for replicon inhibition, led to the identification of two potent constituents present in just trace amounts in the cell media [22, 23]. A preparative experiment allowed isolation of a sufficient quantity of each component to allow for a more detailed characterization. ${ }^{1} \mathrm{H}-\mathrm{NMR}$ and mass spectrum analyses indicated that the two compounds were dimers with an isomeric relationship and assigned as $\mathbf{1 8}$ based on the absence of the C-5 hydrogen atom of the iminothiazolidinone ring in the ${ }^{1} \mathrm{H}-\mathrm{NMR}$ spectrum and connectivity that was 
confirmed after the analysis of the ${ }^{13} \mathrm{C}-\mathrm{NMR}$ spectrum. Although neither the exact stereo-composition of the benzylic centers of $\mathbf{1 8}$ nor the precise relationship between these two compounds was determined, it is of note that the isomer that was less mobile on a reversed phase column converted to the more mobile isomer upon heating in $\mathrm{CD}_{3} \mathrm{CN}$ at $50^{\circ} \mathrm{C}$, an observation made while conducting an NMR experiment as part of the structure determination process [22]. With the acquisition of these data, the mechanistically holistic picture of the degradation process that is presented in Scheme 1 was proposed. Abstraction of the C-5 hydrogen atom of $\mathbf{8}$ by oxygen, which is a diradical in the ground state, would lead to the $\mathrm{C}-5$ radical 11 that is stabilized in a classic captodative fashion by the adjacent $\mathrm{C}=\mathrm{O}$ moiety, the sulfur atom, and the phenyl substituent $[24,25]$. Combination of $\mathbf{1 1}$ with $\mathrm{O}_{2}$ and hydrogen atom acquisition would lead to the hydroperoxide species 12 which in DMSO would be reduced to alcohol 13, an unstable ring system that would be expected to undergo ring opening to give 14. Reclosure of $\mathbf{1 4}$ would then afford the thiohydantoin 15, which had been isolated in the original DMSO degradation experiment, while hydrolytic decomposition of $\mathbf{1 4}$ would afford acid $\mathbf{1 6}$ and the thiourea 17, the latter of which had also been isolated. However, in cell culture media, the stability of radical 11 is presumably such that dimerization can occur, a process that may well be facilitated by aggregative association of $\mathbf{8}$ and/or $\mathbf{1 1}$ in the aqueous medium.

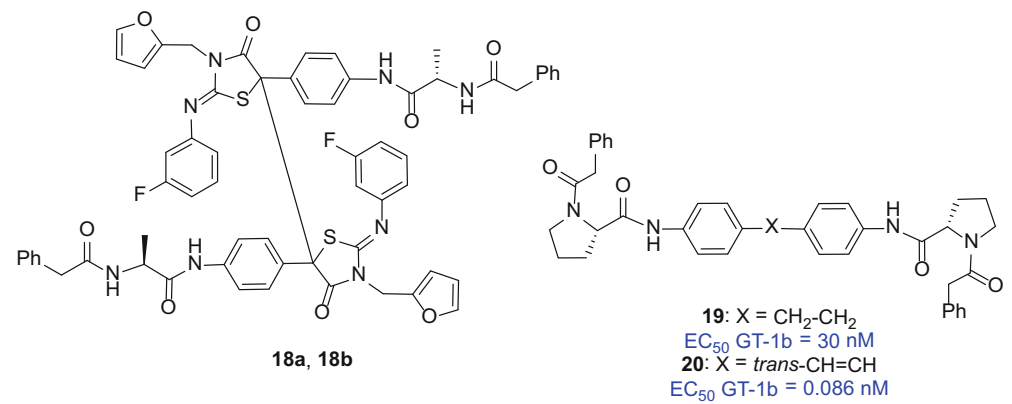

The replicon inhibitory potency of the dimers $18 \mathbf{a}$ and $\mathbf{1 8 b}$ was striking, with the less mobile isomer eluting from the reversed phase chromatography column exhibiting an $\mathrm{EC}_{50}$ value of $600 \mathrm{pM}$ in the GT- $1 \mathrm{~b}$ replicon, while the thermodynamically more stable and chromatographically more mobile isomer was 70 -fold weaker, $\mathrm{EC}_{50}=43 \mathrm{nM}$ $[15,22]$. With the elucidation of the structures of $\mathbf{1 8} \mathbf{a}$ and $\mathbf{1 8 b}$, consideration was given to the concept that the NS5A-inhibiting pharmacophore represented by these dimers may be the embedded symmetrical bibenzyl element. This notion was based on an appreciation of the precise SARs surrounding the amino acid moiety in contrast to the relatively more nebulous effects associated with structural variation to the iminothiazolidinone substituents. Under this concept, the iminothiazolidinone ring system of $\mathbf{2}$ was suggested to act as a scaffolding element by which a bivalent NS5A inhibitor pharmacophore was convened through a radical-mediated dimerization process $[15,22]$. This hypothesis was readily tested in the context of the proline-based chemotype, with 19 demonstrating an $\mathrm{EC}_{50}$ value of $30 \mathrm{nM}$ and confirming the pharmacophore proposal. More interestingly, the unsaturated synthetic precursor 20 
was almost 350-fold more potent than $\mathbf{1 9}, \mathrm{EC}_{50}=0.086 \mathrm{nM}$, providing further insight into the topography of the NS5A-inhibiting pharmacophore.

\section{Optimization of Dimeric NS5A Replication Complex Inhibitors to Daclatasvir}

The discovery of the structurally simpler symmetrical pharmacophore represented by 19 and 20 turned out to be prescient since X-ray crystallographic structure data for NS5A constructs that were published several years after this discovery revealed a dimeric, C2-symmetric protein complex [26-28]. Of note, this structure was determined using a protein construct lacking the membrane-associating amino terminus but, nevertheless, containing some of the key elements of the anticipated binding site for NS5A inhibitors based on the location of resistance mutations. The availability of a structure of the amino terminus of NS5A, acquired by NMR methodology, facilitated the construction of models of NS5A that, when combined with the resistance mutation data, suggested that these compounds bound across the NS5A dimer interface at a site residing between the membrane and the core of the protein. Dimerization of the NS5A protein in cells was subsequently confirmed as was association of NS5A with RNA, a prediction from the X-ray data based on the preponderance of basic amino acids lining the inner surface of the U-shaped dimeric form of NS5A in the solid state [29-32].

While the antiviral activity of $\mathbf{2 0}$ was attractive, there were concerns around elements embedded within the structure, with the olefin observed to be configurationally unstable in some analogues, while the potential for release of one or both aniline moieties after the action of an amidase or protease in vivo raised the specter of toxicity. However, a considerably more challenging problem arose when $\mathbf{2 0}$ was evaluated in a newly developed GT-1a replicon where the compound was found to be poorly active, with an $\mathrm{EC}_{50}$ value that was in excess of $10 \mu \mathrm{M}$. The GT-1a strain of $\mathrm{HCV}$ is clinically relevant, with prevalence that varies across the globe; consequently, securing activity toward this genotype was considered to be a critical objective. Enhancing GT-1a inhibitory activity became the immediate focus of further study, and the approach adopted, while primarily directed toward the peripheral elements, was broad-based in prosecution. Modifications to all facets of the molecule were explored, some of which were also directed toward simultaneously addressing the structural liabilities highlighted above. However, as described below, introducing and retaining GT-1a coverage while optimizing ADME properties would end up posing a considerable challenge. While deeper insight into SARs for GT-1b inhibition emerged from the initial phases of this effort, only a small number of compounds were identified that exhibited modest but reproducible GT-1a inhibition. Among these were the oxazole $\mathbf{2 1}$ and the substituted proline derivative 22, both of which were inhibitory in the GT-1a replicon with $\mathrm{EC}_{50}$ values of less than $1 \mu \mathrm{M}$ [33]. However, attempts to optimize these molecules were unproductive, in each case leading to SAR cul-de-sacs. As the studies progressed, the 2-ethyl-substituted benzamide derivative $\mathbf{2 3}$ and its unsaturated homologue 24 were discovered to 
exhibit weak inhibition of GT-1a and GT-1b replicons, with modeling studies suggesting that the effect of substitution was not a function of modulating the conformation between the phenyl ring and proline carbonyl [34]. The pyridine derivative 25 further advanced the SAR associated with this cap element but, more importantly, formed the basis of the discovery of the isoquinoline derivative $\mathbf{2 6}$, in which the ethyl substituent was incorporated into a fused ring, as the first compound to exhibit potent and balanced antiviral activity toward GT-1a and GT-1b replicons [34]. The promise of this compound was further underscored when it was screened in replicons or hybrid replicons representing genotypes $2 \mathrm{a}, 3 \mathrm{a}$, and $5 \mathrm{a}$ where the $\mathrm{EC}_{50}$ values ranged from 2.2 to $14 \mathrm{nM}$.

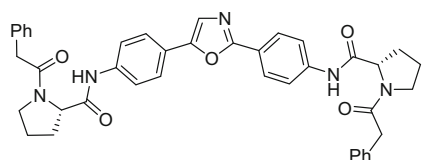

21

$\mathrm{EC}_{50} \mathrm{GT}-1 \mathrm{~b}=0.002 \mu \mathrm{M}$

$\mathrm{EC}_{50} \mathrm{GT}-1 \mathrm{a}=0.345 \mu \mathrm{M}$

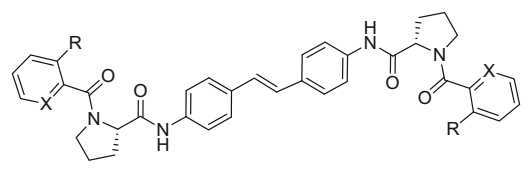

$$
\begin{gathered}
\mathbf{2 3} \\
\mathrm{R}=\mathrm{CH}_{2} \mathrm{CH}_{3} ; \mathrm{X}=\mathrm{CH} \\
\mathrm{EC}_{50} \mathrm{GT}-1 \mathrm{~b}=1.13 \mu \mathrm{M} \\
\mathrm{EC}_{50} \mathrm{GT}-1 \mathrm{a}=\sim 1.00 \mu \mathrm{M} \\
\mathbf{2 4} \\
\mathrm{R}=\mathrm{CH}=\mathrm{CH}_{2} ; \mathrm{X}=\mathrm{CH} \\
\mathrm{EC}_{50} \mathrm{GT}-1 \mathrm{~b}=1.2 \mu \mathrm{M} \\
\mathrm{EC}_{50} \mathrm{GT}-1 \mathrm{a}=1.1 \mu \mathrm{M} \\
\mathbf{2 5} \\
\mathrm{R}=\mathrm{CH}_{2} \mathrm{CH}_{3} ; \mathrm{X}=\mathrm{N} \\
\mathrm{EC}_{50} \mathrm{GT}-1 \mathrm{~b}=0.046 \mu \mathrm{M} \\
\mathrm{EC}_{50} \mathrm{GT}-1 \mathrm{a}=0.72 \mu \mathrm{M}
\end{gathered}
$$

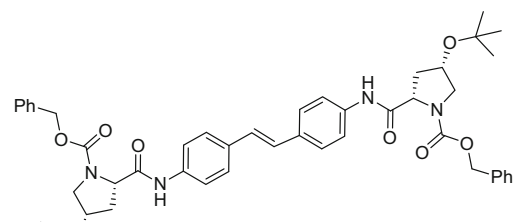<smiles>CC(C)(C)O</smiles>

$\begin{aligned} 22 \\ \mathrm{EC}_{50} \mathrm{GT}-1 \mathrm{~b}\end{aligned}=0.35 \mu \mathrm{M}$ $\mathrm{EC}_{50} \mathrm{GT}-1 \mathrm{a}=0.50 \mu \mathrm{M}$

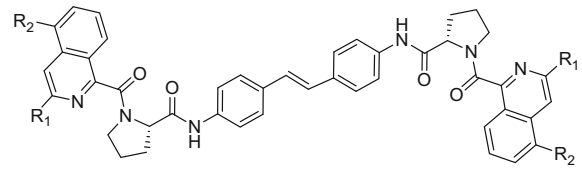

26

$$
\begin{gathered}
\mathrm{R}_{1}=\mathrm{Cl}, \mathrm{R}_{2}=\mathrm{OMe}, \\
\mathrm{EC}_{50} \mathrm{GT}-1 \mathrm{~b}=7 \mathrm{nM} \\
\mathrm{EC}_{50} \mathrm{GT}-1 \mathrm{a}=19 \mathrm{nM} \\
\mathbf{2 7} \\
\mathrm{R}_{1}=\mathrm{R}_{2}=\mathrm{H}, \\
\mathrm{EC}_{50} \mathrm{GT}-1 \mathrm{~b}=22 \mathrm{nM} \\
\mathrm{EC}_{50} \mathrm{GT}-1 \mathrm{a}=390 \mathrm{nM}
\end{gathered}
$$

Further examination of the SARs revealed that GT-1a inhibitory activity was much more sensitive to the nature and the substitution pattern of the isoquinoline ring than GT-1b [34]. For example, 27, the parental analogue of 26, exhibited GT-1a and GT-1b EC 50 values that were 20- and 3-fold weaker than that of $\mathbf{2 6}$, respectively. In addition, the methoxy-substituted derivative $\mathbf{2 8}$ and its chloro-substituted analogue 29 retained potent GT-1b inhibition, but their GT-1a $\mathrm{EC}_{50}$ values were $>10 \mu \mathrm{M}$. However, a more fruitful avenue of investigation was found when the effects of deannulating the isoquinoline ring were probed [35]. The $\alpha$-keto amide $\mathbf{3 0}$ preserved the GT-1a inhibition exhibited by 26, while the derived secondary alcohols $\mathbf{3 1}$ and $\mathbf{3 2}$ demonstrated that planarity at this site was not a specific requirement. The tertiary alcohol homologues $\mathbf{3 3}$ and $\mathbf{3 4}$ added further to the SARs, with the $(S, S)$-analogue $\mathbf{3 4}$ the more potent isomer, particularly toward the $\mathrm{GT}-1 \mathrm{~b}$ replicon where the $\mathrm{EC}_{50}$ value was 6 pM. Another encouraging observation was made with 35 which, although poorly active in the GT-1a replicon, demonstrated 64\% bioavailability following oral dosing to rats, indicating that securing systemic exposure after oral delivery of these symmetrical stilbene derivatives was feasible. 


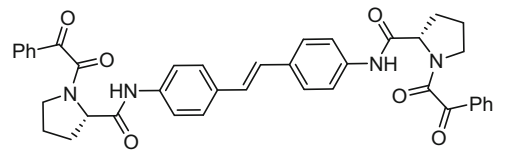

30

$\mathrm{EC}_{50} \mathrm{GT}-1 \mathrm{~b}=8 \mathrm{nM}$

$\mathrm{EC}_{50} \mathrm{GT}-1 \mathrm{a}=447 \mathrm{nM}$

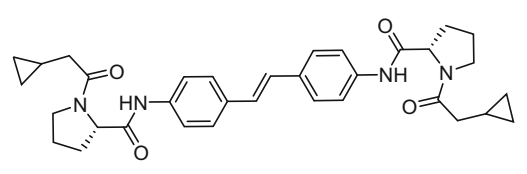

35

$$
\begin{gathered}
\mathrm{EC}_{50} \mathrm{GT}-1 \mathrm{~b}=62 \mathrm{nM} \\
\mathrm{F} \text { in rats }=64 \%
\end{gathered}
$$

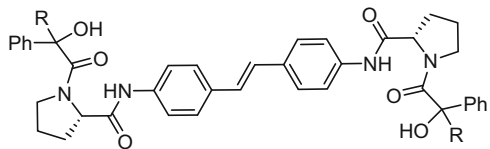

31: $\mathrm{R}=\mathrm{H},(R, R)$ $\mathrm{EC}_{50} \mathrm{GT}-1 \mathrm{~b}=0.022 \mathrm{nM}$ $\mathrm{EC}_{50} \mathrm{GT}-1 \mathrm{a}=640 \mathrm{nM}$ 32: $\mathrm{R}=\mathrm{H},(S, S)$ $\mathrm{EC}_{50} \mathrm{GT}-1 \mathrm{~b}=\sim 4.2 \mathrm{nM}$ $\mathrm{EC}_{50} \mathrm{GT}-1 \mathrm{a}=1020 \mathrm{nM}$

33: $\mathrm{R}=\mathrm{CH}_{3},(R, R)$ $\mathrm{EC}_{50} \mathrm{GT}-1 \mathrm{~b}=<4.6 \mathrm{nM}$ $\mathrm{EC}_{50} \mathrm{GT}-1 \mathrm{a}=6850 \mathrm{nM}$ 34: $\mathrm{R}=\mathrm{CH}_{3},(S, S)$ $\mathrm{EC}_{50} \mathrm{GT}-1 \mathrm{~b}=0.006 \mathrm{nM}$ $\mathrm{EC}_{50} \mathrm{GT}-1 \mathrm{a}=84 \mathrm{nM}$

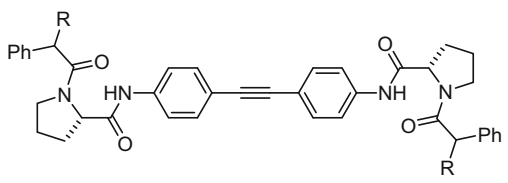

36: $\mathrm{R}=(R, R)-\mathrm{N}\left(\mathrm{CH}_{3}\right)_{2}$ $\mathrm{EC}_{50} \mathrm{GT}-1 \mathrm{~b}=<4.6 \mathrm{nM}$ $\mathrm{EC}_{50} \mathrm{GT}-1 \mathrm{a}=8.8 \mathrm{nM}$ 37: $\mathrm{R}=(\mathrm{S}, \mathrm{S})-\mathrm{N}\left(\mathrm{CH}_{3}\right)_{2}$ $\mathrm{EC}_{50} \mathrm{GT}-1 \mathrm{~b}=<4.6 \mathrm{nM}$ $\mathrm{EC}_{50} \mathrm{GT}-1 \mathrm{a}=628 \mathrm{nM}$
38: $\mathrm{R}=(R, R)-\mathrm{NHCO}_{2} \mathrm{CH}_{2}$ $\mathrm{EC}_{50} \mathrm{GT}-1 \mathrm{~b}=0.013 \mathrm{nM}$ $\mathrm{EC}_{50} \mathrm{GT}-1 \mathrm{a}=26 \mathrm{nM}$

Replacing the stilbene element with an alkyne, which resolved a cis-trans isomerization issue observed with some analogues, added further to the understanding of the topography of the pharmacophore. Additional probing of the amino acid terminal region using this alkyne-based scaffold identified potent arylglycine-based analogues for which the GT-1a $\mathrm{EC}_{50}$ values for some compounds, including 36-38, were single digit $\mathrm{nM}$ [35]. Notably, the change in stereochemical preference in evolving the chemotype from the mandelamide analogues $\mathbf{3 3}$ and $\mathbf{3 4}$ to the phenylglycine analogues $\mathbf{3 6}$ and $\mathbf{3 7}$ further highlighted the relatively intricacy and sensitivity of the GT-1a inhibition SARs that were being uncovered during this phase of the project. Equally intriguing was the accumulating evidence indicating that the GT-1b virus was highly tolerant of many structural changes, an observation that could not readily be explained based on the differences in amino acid composition at the putative binding site of the compounds.

A concurrent effort examined scaffold modifications directed toward the identification of a less problematic replacement for the anilide moiety that would decrease or eliminate the potential for aniline release in vivo which led to the emergence of two noteworthy SAR findings. Firstly, the replacement of the anilide moieties of $\mathbf{3 6}$ and 38 with a benzimidazole, a design intended to preserve both the H-bond donor and acceptor properties of the anilide, resulted in a 4- to 30-fold reduction in potency toward the GT-1a replicon, as exemplified by 39 and 40 [36]. Secondly, a mix and match SAR exercise accentuated the sensitivity of GT-1a inhibitory potency to topological parameters, exemplified by the 70-fold difference in GT-1a inhibitory potency between regioisomers $\mathbf{4 1}$ and $\mathbf{4 2}$.

These SAR findings were attributed to the altered topology of the peripheral pharmacophoric elements with respect to the core, a shortcoming that was ultimately addressed by the biphenyl derivatives 43 and 44 which recapitulate the linearity 
associated with the core alkynes in $\mathbf{3 6 - 4 0}$. In $\mathbf{4 3}$ and $\mathbf{4 4}$, a motif that was arrived at only after considerable experimentation, deannelation of the benzimidazole ring provided a structural arrangement that compensated for the reduced length of the core of the pharmacophore relative to $\mathbf{3 9}$ and $\mathbf{4 0}$. The success of this design strategy is readily apparent since both $\mathbf{4 3}$ and $\mathbf{4 4}$ are exquisitely potent $\mathrm{HCV}$ antiviral agents with balanced GT-1a and GT-1b inhibition, with $\mathrm{EC}_{50}$ values ranging from 7 to $42 \mathrm{pM}$ [4]. However, the oral bioavailability and systemic exposure of both $\mathbf{4 3}$ and 44 in the rat were poor, a result attributed, in part, to the high molecular weight (747 and $807 \mathrm{Da}$, respectively) and structural composition. This notion was reinforced by PK studies with the smaller ( $\mathrm{MW}=713$ ) and unsymmetrical tetrahydrofuran $\mathbf{4 5}$ which divests of a H-bond donor. Although the oral bioavailability of $\mathbf{4 5}$ was low in rodents ( $\mathrm{F}$ in mouse $=17 \%, \mathrm{~F}$ in rat $=6.8 \%$ ), its exposure in the dog was much improved, with bioavailability measured at $45 \%$. In an effort to reduce the molecular weight of the carbamate $\mathbf{4 4}$, the two aromatic rings of the phenyl glycine moiety were curtailed to isopropyl substituents affording the D-valine derivative $\mathbf{4 6}$. However, this structural modification resulted in a significant reduction in potency toward both HCV genotypes, with the GT-1a inhibition particularly sensitive, eroding by 44,000 -fold. This SAR observation took some time to understand and was resolved only after further study of the chemotype, which revealed that the preferred absolute configuration of the alkyl-glycine caps was the opposite of that of the aryl-glycine caps. The initial observation in this direction was made when the tetrahydrofuran ring of $\mathbf{4 5}$ was replaced with L-alanine to provide $\mathbf{4 7}$, which restored potency to sub-nanomolar levels. In an observation that proved to be pivotal, the symmetrical alanine derivative $\mathbf{4 8}$ performed similarly, and further optimization of the amino acid appendage led to the discovery of the bis-L-valine derivative $\mathbf{1}$, an exercise that also included assessing the potential of unsymmetrical derivatives. The decision to advance $\mathbf{1}$ into IND-enabling toxicology evaluation was taken after a careful comparison with $\mathbf{4 9}$, an analogue with two changes to the periphery that demonstrated similar antiviral properties to $\mathbf{1}$ (Table 2) but a different PK profile (Table 3). The decision to select 1 for development rather $\mathbf{4 9}$ was based on the observation of a twofold accumulation of the latter compound in the plasma, livers, and hearts of mice after 4 days of daily drug administration which occurred at all of the dose levels $(15,50$, and $100 \mathrm{mg} / \mathrm{kg})$ examined.

Table 2 Inhibition of replicons and hybrid replicons by 1 and 49

\begin{tabular}{l|l|l}
\hline Replicon genotype $^{\mathrm{a}}$ & $\mathrm{EC}_{50}$ value for $\mathbf{1}(\mathrm{nM})$ & $\mathrm{EC}_{50}$ value for $\mathbf{4 9}(\mathrm{nM})$ \\
\hline GT-1a H77 & 0.050 & 0.036 \\
\hline GT-1b Con1 & 0.009 & 0.012 \\
\hline GT-2a JFH-1 & 0.071 & 0.020 \\
\hline GT-3a & 0.146 & 0.008 \\
\hline GT-4a & 0.012 & 0.014 \\
\hline GT-5a & 0.033 & 0.021 \\
\hline GT-6 & 0.054 & ND \\
\hline
\end{tabular}

${ }^{a}$ With the exception of GT-2a JFH-1, all data are from hybrid replicons in either a GT-2a JFH-1 or GT-1b Con1 backbone: GT-3a (1-100 NS5A amino acid in Con1); GT-4a (full-length NS5A in Con1); GT-5a (1-110 NS5A amino acid in JFH-1); GT-6a (full-length NS5A in JFH-1) 
The Discovery and Development of Daclatasvir: An Inhibitor of the...

Table 3 Pharmacokinetic profile of $\mathbf{1}$ and $\mathbf{4 9}$ in preclinical species

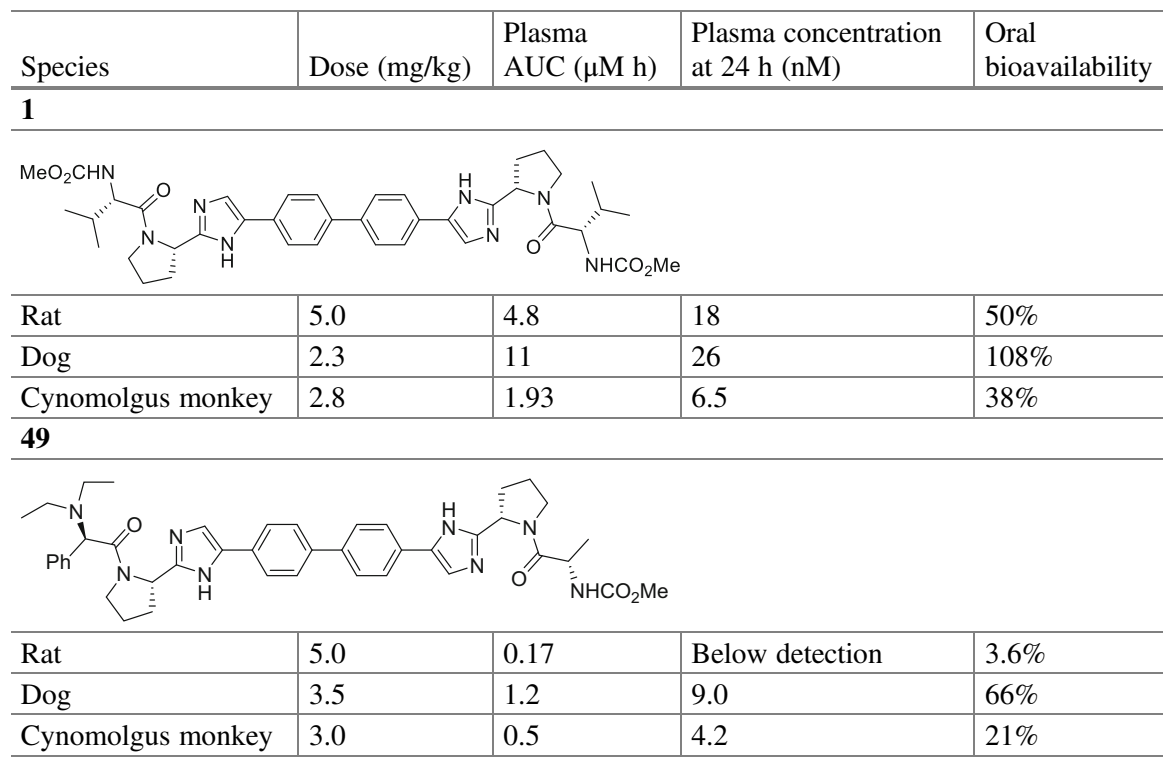

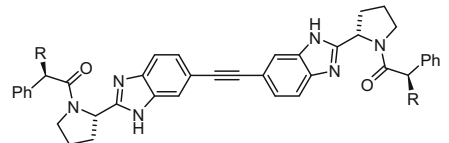

39: $\mathrm{R}=\mathrm{N}\left(\mathrm{CH}_{3}\right)_{2}$ $\mathrm{EC}_{50} \mathrm{GT}-1 \mathrm{~b}=0.09 \mathrm{nM}$ $\mathrm{EC}_{50} \mathrm{GT}-1 \mathrm{a}=260 \mathrm{nM}$ 40: $\mathrm{R}=\mathrm{NHCO}_{2} \mathrm{CH}_{3}$ $\mathrm{EC}_{50} \mathrm{GT}-1 \mathrm{~b}=0.055 \mathrm{nM}$

$\mathrm{EC} 50 \mathrm{GT}-1 \mathrm{a}=108 \mathrm{nM}$

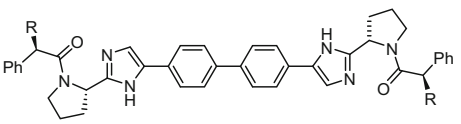

43: $\mathrm{R}=\mathrm{N}\left(\mathrm{CH}_{3}\right)_{2}$ EC $\mathrm{GT}-1 \mathrm{~b}=0.042 \mathrm{nM}$ $\mathrm{EC}_{50} \mathrm{GT}-1 \mathrm{a}=0.038 \mathrm{nM}$ 44: $\mathrm{R}=\mathrm{NHCO}_{2} \mathrm{CH}_{3}$ $\mathrm{EC}_{50} \mathrm{GT}-1 \mathrm{~b}=0.007 \mathrm{nM}$

$\mathrm{EC}_{50} \mathrm{GT}-1 \mathrm{a}=0.028 \mathrm{nM}$
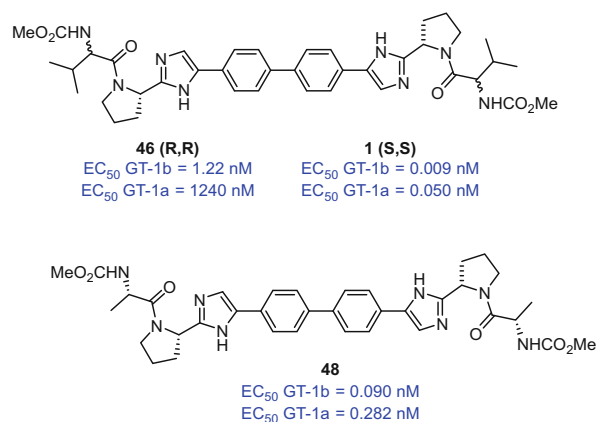

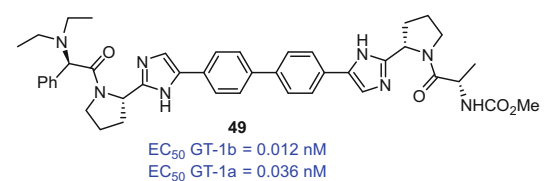

$\mathrm{EC}_{50} \mathrm{GT}-1 \mathrm{~b}=0.015 \mathrm{nM}$ $\mathrm{EC}_{50} \mathrm{GT}-1 \mathrm{a}=138 / \mathrm{nM}$ F: rat $(6.8 \%)$, mouse $(17 \%), \operatorname{dog}(45 \%)$

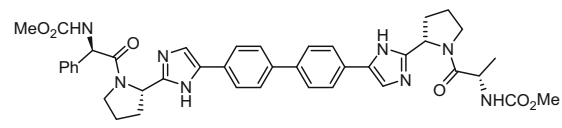

47

$\mathrm{EC}_{50} \mathrm{GT}-1 \mathrm{~b}=0.013 \mathrm{nM}$ $\mathrm{EC}_{50} \mathrm{GT}-1 \mathrm{a}=0.112 \mathrm{nM}$

EC GT $-1 \mathrm{a}=0.036 \mathrm{nM}$ 
The antiviral profiles of $\mathbf{1}$ and $\mathbf{4 9}$ toward wild-type and hybrid replicons representing all of the genotypes and subtypes that were available at the time are summarized in Table $2[1-4,37-40]$. Adding to confidence in the potential of $\mathbf{1}$ as it negotiated the development path toward clinical evaluation was the potent inhibition observed in a newly established GT-2a JFH-replicating virus assay. The $\mathrm{EC}_{50}$ value of $28 \mathrm{pM}$ in this assay exhibited a good correlation with the inhibitory potency toward the GT-2a JFH replicon [1-4].

The pharmacokinetic parameters of $\mathbf{1}$ and $\mathbf{4 9}$ in rat, dog, and cynomolgus monkey are compiled in Table 3 and demonstrate good systemic exposure following oral administration, with the drug concentration measured at $24 \mathrm{~h}$ post-dose well in excess of the $\mathrm{EC}_{50}$ values for the GT-1a and GT-1b replicons and the proteinbinding-adjusted $\mathrm{EC}_{90}$ value of $383 \mathrm{pM}$ determined for the GT-1a replicon. More importantly, target organ exposure was also demonstrated, with liver levels of $103 \mathrm{nM}$ measured in the rat $24 \mathrm{~h}$ following a $5 \mathrm{mg} / \mathrm{kg}$ dose of $\mathbf{1}$, a concentration that was fivefold higher than that in plasma. The favorable absorption properties of 1 have been attributed, in part, to the formation of an intramolecular H-bond between the carbamate $\mathrm{C}=\mathrm{O}$ and imidazole $\mathrm{N}-\mathrm{H}$ moieties that enhances lipophilicity and reduces the apparent PSA of the molecule based on a chromatographic analysis and which is supported by modeling studies [41].

\section{Mode of Action Studies with Daclatasvir}

Despite its high potency and broad genotype inhibitory activity, the precise mode of inhibition of $\mathrm{HCV}$ replication by $\mathbf{1}$ remains as enigmatic as does the biochemical function of the NS5A protein [16, 18, 42-48]. HCV NS5A has no known enzymatic activity but is a critical element in the assembly and function of the replication complex on intracellular membranes and also in virion assembly [16, 4248]. HCV NS5A is a 447-residue phosphoprotein that is comprised of three functional domains and an amphipathic helix at the amino terminus that associates with but does not traverse to biological membranes. Domain 1 contains a $\mathrm{Zn}^{2+}$ binding motif and several serine residues that are sites of basal phosphorylation and hyperphosphorylation. The phosphorylation state of NS5A may modulate its function in virus replication and assembly with the hyperphosphorylated form, which can be produced by the action of the host cell lipid kinase, phosphatidylinositol 4-kinase, involved in the assembly of virions. Domain 2 has been shown to bind to the NS5B RNA-dependent RNA polymerase and has been associated with the sensitivity of the virus to interferon therapy although that function is controversial. While domain 3 appears to play a role in virus replication, it has most prominently been associated with virion assembly. The mapping of resistance mutations arising in response to selective pressure exerted by $\mathbf{1}$ and related analogues to domain 1 of NS5A is consistent with the effect on virus replication, but studies with infectious virus have demonstrated that 1 also interferes with the assembly of virions [42-50]. The 
latter effect has been postulated to explain the rapid decline in viremia observed in $\mathrm{HCV}$-infected patients administered clinically effective doses of $\mathbf{1}$ (vide infra) [3,51]. In addition to associating with all of the viral nonstructural proteins, HCV NS5A has also been shown to bind to an extensive repertoire of host cell proteins that exceeds 130 entities [52-57]. As a consequence, the NS5A protein is typically viewed as a master regulator of virus replication and virion production, orchestrating both viral proteins and the host cell environment to ensure the successful production and release of progeny virus [42-48].

An association of NS5A inhibitors with the viral protein was originally demonstrated by studies with the biotin-labeled derivative $\mathbf{5 0}$ which is an effective inhibitor of GT-1b replication [3]. The antiviral activity of $\mathbf{5 0}$ is highly sensitive to the absolute configuration of the proline moiety since the $(R, R)$-isomer $\mathbf{5 1}$ is inactive, while inhibition is substantially reduced by the Tyr93His resistance mutation that arises in response to virus passaging in the presence of $\mathbf{1}$. This SAR profile is strictly analogous to that established for the stilbene chemotype, and $\mathbf{5 0}$ was thus viewed as a useful tool molecule with which to probe drug-target binding interactions. In an initial experiment, GT-1b replicon lysate was incubated with 50, and the mixture passed over streptavidin immobilized on beads; however, this experimental protocol failed to pull down any viral protein. In contrast, incubating replicon cells with $\mathbf{5 0}$ for $18 \mathrm{~h}$ before lysing and passing the lysate over streptavidin beads identified only NS5A as a binding partner, while a control experiment with inactive diastereomer $\mathbf{5 0}$ failed to isolate any virial proteins. These results indicate that $\mathbf{5 0}$ binds to HCV NS5A and that binding is dependent on the absolute configuration of the proline element, an observation concordant with the SARs developed in the stilbene-based series.

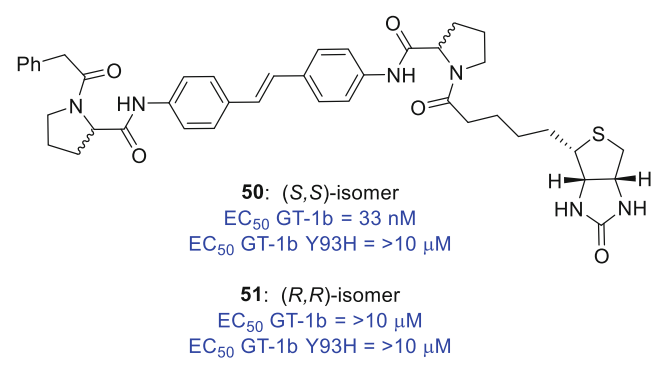

While the experiments conducted with $\mathbf{5 0}$ indicate that the binding of inhibitors to the NS5A is choreographically somewhat complex, the binding of inhibitors of NS5A to both domain 1 and the full-length viral protein was subsequently demonstrated in a series of independent biochemical experiments [58, 59]. These studies have suggested that the binding of inhibitors to NS5A interferes with the association of viral RNA with the protein, with the binding of compounds competed out by other NS5A inhibitors and demonstrating diminished affinity for the Tyr93His mutant protein $[58,59]$. However, profiling of inhibitors in cell-based assays has indicated that disruption of RNA binding to NS5A does not appear to occur and that the introduction of key resistant mutations leads to only a modest reduction in the 
binding of inhibitors [60, 61]. Studies with $\mathbf{5 0}$ in resistant GT-1b replicons indicated that while the Tyr93His-resistant mutation reduced inhibitory potency by 220 -fold, an estimate of the amount of NS5A protein pulled down by the chemical probe, as determined by an analysis of Western blots, suggested similar levels of protein-drug association for the resistant and wild-type strains $[60,61]$. Adding further to the complexity of the biochemistry was the observation that in a protein pull-down experiment, an attempt to outcompete the biotinylated tool compound $\mathbf{5 0}$ with a non-biotinylated analogue in a GT-1b Tyr93His-containing mutant $\left(\mathrm{EC}_{50}=290 \mathrm{nM}\right.$ for stated analogue vs $>7 \mu \mathrm{M}$ for 50) not only failed but, at low concentration, appeared to have incrementally enhanced the amount of NS5A pulled down. From these data, it was inferred that the development of resistance to $\mathbf{1}$ does not lead to exclusion of binding to the NS5A protein, as is often observed with other classes of antiviral agents. Rather, these observations suggested a scenario in which HCV NS5A develops resistance by accommodating rather than expelling inhibitors, with the mutations presumably allowing restoration of protein function in the presence of the bound inhibitor. Consistent with this suggestion, several of the resistant mutations incorporate smaller or more flexible amino acid side chains, exemplified by Tyr93His, Tyr93Cys, Leu31Met, and Leu31Val, which may restore conformational flexibility compromised by the binding of inhibitors. These observations stimulated an experiment designed to evaluate the effect of combining 1 with structurally related compounds on the function of HCV NS5A incorporating resistance mutations. Two possible outcomes were contemplated: in the first scenario, a molecule would simply compete with bound $\mathbf{1}$ and the observed effect would be one of silence. However, the alternative scenario speculated on the potential of a second molecule to act in conjunction with $\mathbf{1}$ to restore inhibition by binding to an adjacent site on the NS5A molecule. A screen of compounds selected from the library of HCV NS5A inhibitors assessed in the presence of $\mathbf{1}$ using the Tyr93Asn GT-1aresistant replicon, followed by SAR optimization, identified Syn-395 (52) as a molecule capable of restoring the sensitivity of resistant virus to the inhibitory effects of $\mathbf{1}$. For example, in a typical experiment, $\mathbf{1}$ exhibited $\mathrm{EC}_{50}$ values of $33 \mathrm{pM}$ and $339 \mathrm{nM}$ toward the wild type and Tyr93Asn mutant replicons, respectively, whereas $\mathbf{5 2}$ was poorly active in both replicons, with $\mathrm{EC}_{50}$ values of 214 and $215 \mathrm{nM}$, respectively. However, the $\mathrm{EC}_{50}$ of $\mathbf{1}$ toward the Tyr93Asn mutant replicon improved to $0.13 \mathrm{nM}$ when titrated in the presence of a suboptimal concentration $(40 \mathrm{nM})$ of 52. This result represented a 2,600-fold increase in the sensitivity of the Tyr93Asn replicon to $\mathbf{1}$ in the presence of $\mathbf{5 2}$. The synergistic relationship between $\mathbf{1}$ and $\mathbf{5 2}$ was confirmed in a reciprocal experiment where $\mathbf{5 2}$ was titrated in the presence of suboptimal amount of $\mathbf{1}$ affording a similar outcome [60, 61].

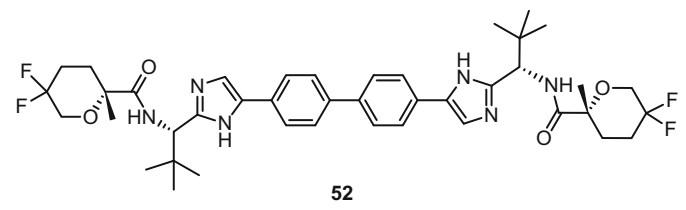

These observations, taken together with the absence of structural data that holistically captures the HCV NS5A drug-binding sites in the context of the membrane- 
bound replication complex, confer considerable complexity on the nature of drugtarget interactions, the mode of inhibition, and the function of the NS5A protein. This has presented a significant challenge to developing a more coherent and detailed understanding of the mechanism of action of HCV NS5A inhibitors and the modeling of drug-target interactions of these potent antiviral agents and the allosteric modulators [60-67]. While the bivalent nature of NS5A inhibitors, including the allosteric modulators represented by $\mathbf{5 2}$, complements the dimeric form of the protein observed in solid-state structures of elements of domain I, the binding interfaces between the proteins vary [26-28, 60, 61]. One interpretation of this observation anticipates an oligomeric form of HCV NS5A in cells that can bind to the viral RNA and protect it from chemical and enzymatic degradation while providing a platform for RNA presentation to the polymerase and translocation to the developing virion [6870]. However, the biochemical pharmacological effects of NS5A inhibitors are multifaceted and complex and include altering the subcellular distribution of NS5A, modulating the phosphorylation state of the protein, interfering with the formation of the membranous factories where virus replication occurs, and blocking the transfer of the viral genome to assembly proteins, leading to a clustering of $\mathrm{HCV}$ proteins at endoplasmic reticulum membranes [71-76].

\section{Clinical Trials with Daclatasvir}

The phase I clinical trial with $\mathbf{1}$ comprised of a randomized, double-blind, placebocontrolled, single ascending dose study involving administration of 1, 10, 25, 50, 100 , and $200 \mathrm{mg}$ of the drug to normal healthy volunteers (NHVs) [3]. A doseproportional increase in plasma exposure was observed over the dosing range, and the concentration of 1 in plasma $24 \mathrm{~h}$ after dosing exceeded the protein-bindingadjusted $\mathrm{EC}_{90}$ values of $49 \mathrm{pM}(0.04 \mathrm{ng} / \mathrm{mL})$ and $383 \mathrm{pM}(0.28 \mathrm{ng} / \mathrm{mL})$ recorded for the GT-1b and GT-1a replicons, respectively [3]. Compound $\mathbf{1}$ was quickly absorbed and exposure extended beyond $24 \mathrm{~h}$, with plasma drug concentration maintained above the less sensitive GT-1a protein-binding-adjusted $\mathrm{EC}_{90}$ value of $383 \mathrm{pM}$ at $72 \mathrm{~h}$ for all but the $1 \mathrm{mg}$ dose, predicting the potential for once-daily dosing [51]. The absolute oral bioavailability of $\mathbf{1}$ in humans is $67 \%$, and the compound is $\sim 99 \%$ bound to plasma proteins [77-80]. In this trial, $\mathbf{1}$ was safe and well tolerated at all of the administered doses with no clinically significant adverse effects observed, a profile that set the stage for a proof-of-concept study in HCV GT-1infected subjects. Doses of 1, 10, and $100 \mathrm{mg}$ were administered in a randomized, double-blind, placebo-controlled, single ascending dose format similar to that used for the NHV study, and plasma HCV RNA levels were monitored until $172 \mathrm{~h}$ postdose. The results of this study are compiled in Table 4 with mean plasma HCV RNA declining by $1.8 \log _{10} \mathrm{IU} / \mathrm{mL} 24 \mathrm{~h}$ following the $1 \mathrm{mg}$ dose, while the 10 and $100 \mathrm{mg}$ doses provided increased efficacy, with viral load declines of 3.2 and $3.3 \log _{10}$ $\mathrm{IU} / \mathrm{mL}$, respectively, measured at $24 \mathrm{~h}$. The mean maximal viral load reduction in the $100 \mathrm{mg}$ dose cohort was $3.6 \log _{10} \mathrm{IU} / \mathrm{mL}$ with HCV RNA measured at $35 \mathrm{IU} / \mathrm{mL}$ in one of the GT-1b-infected subjects, while plasma RNA in another was below the 
Table 4 Dose, HCV genotype distribution, and plasma HCV RNA levels following administration of 1 to $\mathrm{HCV}$-infected subjects

\begin{tabular}{l|l|l|l}
\hline Dose of 1 & $1 \mathrm{mg}$ & $10 \mathrm{mg}$ & $100 \mathrm{mg}$ \\
\hline GT-1a/1b & $6 / 0$ & $3 / 2$ & $2 / 3^{\mathrm{a}}$ \\
\hline $\begin{array}{l}\text { Mean viral load reduction } \\
\text { at } 24 \mathrm{~h}(\text { range) }\end{array}$ & $1.8 \log _{10}(0.2-3.0$ & $3.2 \log _{10}(2.9-4.0$ & $3.3 \log _{10}(2.7-3.6$ \\
$\left.\log _{10}\right) \mathrm{IU} / \mathrm{mL}$ & $\left.\log _{10}\right) \mathrm{IU} / \mathrm{mL}$ & $\mathrm{IU} / \mathrm{mL}$ \\
\hline $\begin{array}{l}\text { Mean maximal reduction } \\
\text { in viral load }\end{array}$ & & & $\begin{array}{l}3.6 \log _{10}(3.0-4.1 \\
\left.\log _{10}\right) \mathrm{IU} / \mathrm{mL}\end{array}$ \\
\hline
\end{tabular}

${ }^{\mathrm{a}}$ One subject withdrew $8 \mathrm{~h}$ after dosing of $\mathbf{1}$

lower limit of quantification $(25 \mathrm{IU} / \mathrm{mL})$ at $144 \mathrm{~h}$ post-dose. The decline in plasma viral RNA concentration following administration of the 10 and $100 \mathrm{mg}$ doses of 1 was both rapid and profound in nature, with a mean reduction of $1.95 \log _{10} \mathrm{IU} / \mathrm{mL}$ measured at $6 \mathrm{~h}$ post-dose for nine of the patients $[49,51]$. The steep decline in viral load was subsequently explained after the development of a multiscale model of viral kinetics that took into account the effects of $\mathbf{1}$ on both viral replication and virus assembly and secretion, with the latter being the source of an immediate effect on virion production. The mean effectiveness of $\mathbf{1}$ on virus RNA production and virion assembly/secretion was estimated to be 99 and $99.8 \%$, respectively, and yielded an estimate of plasma HCV half-life of $45 \mathrm{~min}$, significantly shorter than the $2.7 \mathrm{~h}$ halflife estimated from an analysis of viral kinetics during treatment with older, interferon-based therapies [49].

The profile of 1 was further explored in a double-blind, placebo-controlled multiple ascending dose study in which the drug was administered for 14 consecutive days to GT-1-infected subjects at doses of 1, 10, 30, 60, and $100 \mathrm{mg}$ once daily and $30 \mathrm{mg}$ twice daily [51]. Each panel comprised of five patients randomized such that four received drug and one was administered a placebo control, with drug PK parameters determined on days 1 and 14. Median peak plasma concentrations of 1 occurred 1-2 h after dosing, and the PK profile was supportive of once-daily dosing with a mean terminal half-life of $12-15 \mathrm{~h}$ and steady state achieved after 3-4 days of drug administration. The mean maximal reduction in HCV RNA levels in plasma are compiled in Fig. 3 with 30 and 60 mg QD cohorts comprised solely of GT-1a-infected subjects. In the other dosing cohorts, those infected with GT-1b virus exhibited a greater response compared to those infected with GT-1a virus. However, most patients experienced viral rebound on or before day 7 of therapy with viral RNA levels below the mean maximal decline except in the $30 \mathrm{mg}$ BID cohort (Fig. 4). Rebound was typically more rapid in the GT-1a-infected subjects which can be explained by a lower genetic barrier to resistance in this subtype [81-83]. In HCV GT-1a, only a single base pair change in the viral RNA is typically required to code for an alternative amino acid, while GT-1b frequently requires two base pair changes for coherent coding [8183]. Population sequencing indicated the appearance of mutations at Met28, Gln30, Leu31, and Tyr93 all of which had been identified as resistance mutation hotspots in response to selective pressure by $\mathbf{1}$ in replicon studies in vitro [84, 85].

While the results of this trial further confirmed the potential of HCV NS5A as a therapeutic target, the rapid emergence of resistance to $\mathbf{1}$ anticipated that optimal 


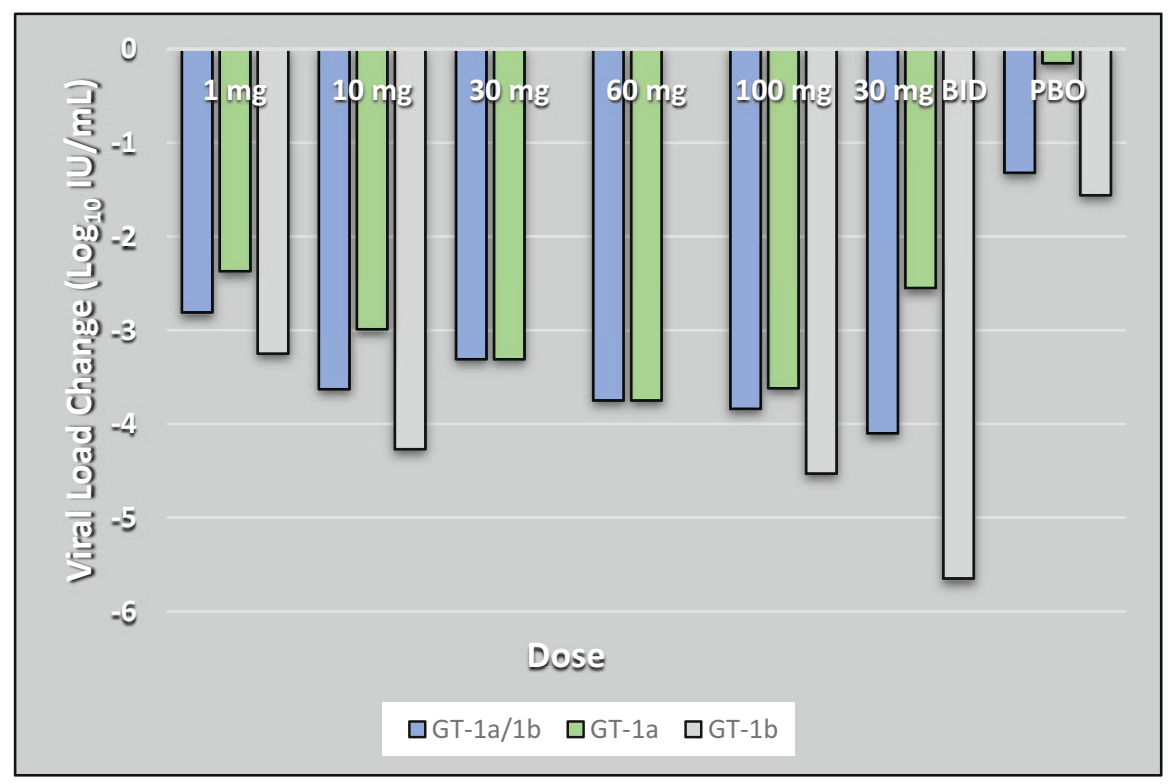

Fig. 3 Mean maximum decrease in plasma viral RNA in HCV GT-1-infected subjects following dosing of $\mathbf{1}$ for 14 days

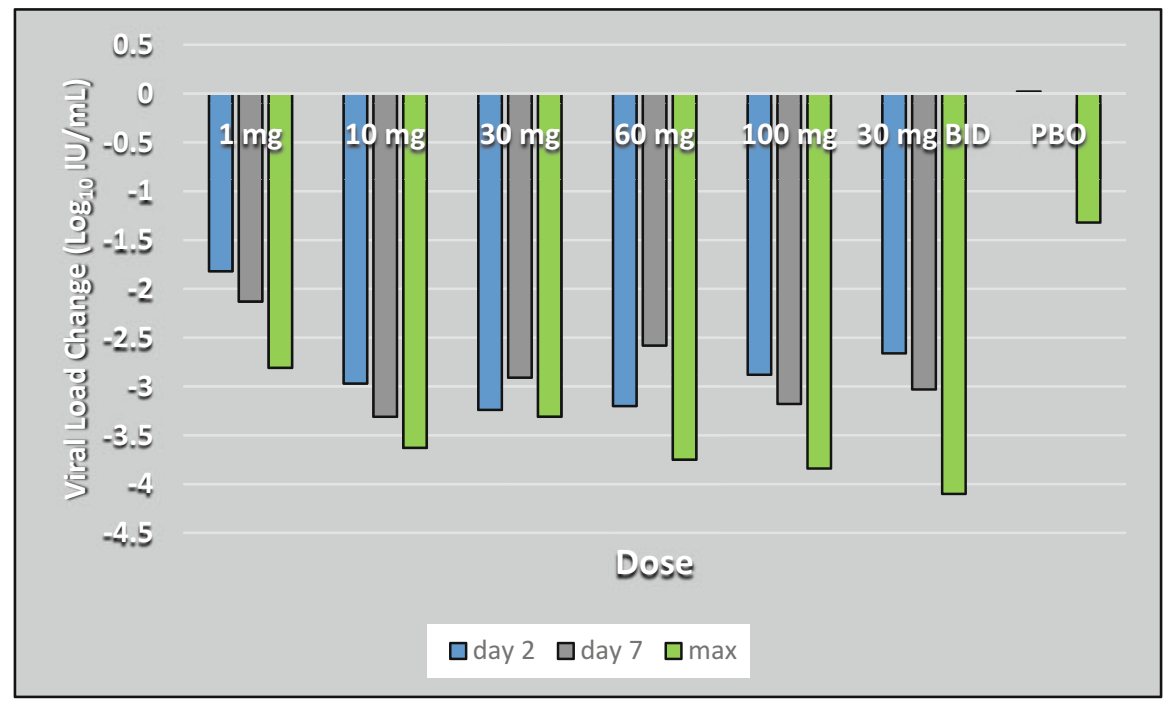

Fig. 4 Mean viral load reductions on days 2 and 7 compared with the maximal viral RNA decline following dosing of $\mathbf{1}$ 
clinical application would be as part of combination therapy [79, 81-91]. The combination of $\mathbf{1}$ as add-on therapy to the extant standard of care, pegylated IFN $\alpha$ and ribavirin (53), was explored clinically in patients infected with HCV genotypes 1-4 and a subset of patients who were co-infected with HIV-1. The results indicated that sustained virologic responses could be achieved with shorter 24-week durations of therapy with a burden of side effects comparable to that of pegylated IFN $\alpha$ and $\mathbf{5 3}$ [92-96]. However, it was the opportunity availed by the contemporaneous development of the HCV NS3 protease inhibitor asunaprevir (54) that allowed the pursuit of a parallel clinical program that had a significant impact on the course of the clinical development of HCV therapeutic agents [97-102]. In a small open-label clinical trial conducted in HCV GT-1-infected subjects who had no evidence of cirrhosis and who had previously failed to respond to peg-IFN/53 therapy (referred to as null responders), a combination of $\mathbf{1}$ (60 mg QD PO) and $\mathbf{5 4}$ (600 mg BID PO) with peg-interferon $\alpha 2 \mathrm{a}(180 \mu \mathrm{g}$ per week subcutaneously) and $\mathbf{5 3}(1,000$ or $1,200 \mathrm{mg}$ QD PO, depending on body weight) administered for 24 weeks was compared with a regimen comprised of only the two direct-acting antiviral agents (DAAs) $[99,102]$. All of the ten patients receiving the quadruple drug regimen had undetectable levels of HCV RNA in plasma measured at 12 weeks following the last dose $\left(\mathrm{SVR}_{12}\right)$, while nine also achieved $\mathrm{SVR}_{24}$. One patient in this group had detectable HCV RNA in plasma at week 24, but this was not quantifiable, and viral RNA was not detected in plasma 5 weeks later $[99,102]$. Of the 11 patients receiving only the dual DAA combination, five had undetectable levels of HCV RNA in plasma at the end of therapy, and four maintained this status at weeks 4, 12, and 24 after the last drug dose. This cohort was comprised of nine subjects infected with GT-1a and two infected with GT-1b, with both GT-1b-infected patients achieving $\mathrm{SVR}_{24}$, while six patients infected with GT-1a virus experienced virological breakthrough while on therapy and the remaining patient infected with GT-1a virus relapsed after completing drug therapy. This study, which was conducted in a very challenging patient population, provided the first indication that a chronic $\mathrm{HCV}$ infection could be cured solely by treatment with DAAs in the absence of the immune stimulation provided by peg-interferon $\alpha 2 \mathrm{a}$ and $\mathbf{5 3}$ [100].

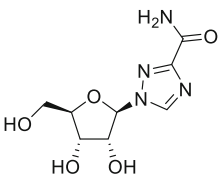

53 (ribavirin)

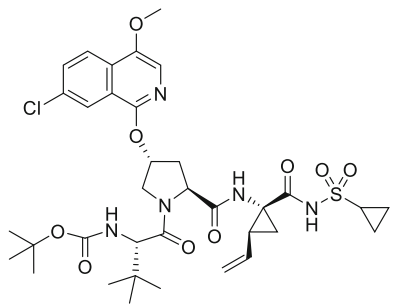

54 (asunaprevir)

The successful treatment of HCV GT-1b infections with $\mathbf{1}$ and $\mathbf{5 4}$ redirected the clinical development plan for this dual combination to Japan where GT-1b is the 
most prevalent, accounting for approximately $70 \%$ of the estimated two million infections at the time [103, 104]. The combination of $\mathbf{1}$ and $\mathbf{5 4}$ has been studied extensively in GT-1b-infected Japanese patients, leading to approval of the drug combination by the Japanese Pharmaceutical and Medical Devices Agency (PMDA) on July 4, 2014 [105-119]. The marketing authorization of 1 as Daklinza ${ }^{\mathrm{TM}}$ and $\mathbf{5 4}$ as Sunvepra ${ }^{\circledR}$ in Japan represented the first approval of a combination of DAAs for the treatment of HCV infection although the combination of sofosbuvir (55) and $\mathbf{5 3}$ had been approved by the FDA in December of 2013 [107]. The phase III Japanese clinical trials of 1 (60 mg QD) and 54 (100 mg BID) in GT-1b-infected subjects that subtended marketing approval evaluated 24 weeks of therapy and were associated with $\mathrm{SVR}_{12}$ rates of $81 \%$ in non-responders and $87 \%$ in those intolerant of or ineligible for pegylated interferon therapy. In a multinational study conducted in a broad GT-1b patient population, the $\mathrm{SVR}_{12}$ rates were $90 \%$ in those naïve to therapy and $82 \%$ in those intolerant of or ineligible for interferon-based therapies. The pre-existence of the Tyr93His polymorphism in the HCV NS5A gene was a predictor of lower clinical efficacy, with the SVR rates declining to 45 from $95 \%$ in those patients that harbored this mutation at baseline, which has a $15 \%$ prevalence in the Japanese patient population.

Broadening the utility of $\mathbf{1}$ and $\mathbf{5 4}$ to treat HCV GT-1a infections required the addition of a third agent, the allosteric RNA-dependent RNA polymerase inhibitor beclabuvir (56) which was developed as a fixed-dose combination comprising of $30 \mathrm{mg}$ of $\mathbf{1}, 200 \mathrm{mg}$ of $\mathbf{5 4}$, and $75 \mathrm{mg}$ of $\mathbf{5 6}$ administered as a BID regimen for 12 weeks [120-126]. In the UNITY 1 international study which was conducted in 415 non-cirrhotic patients with HCV GT-1 infection, $91 \%$ of the patients achieved $\mathrm{SVR}_{12} . \mathrm{SVR}_{12}$ rates of $92 \%$ were observed in treatment-naive patients and $89 \%$ in treatment-experienced patients, while virologic failure occurred in $8 \%$ of the patients. In the UNITY-2 phase III study conducted in the United States, Canada, France, and Australia in 202 GT-1-infected patients with compensated cirrhosis, the $\mathrm{SVR}_{12}$ rates were $93 \%$ for patients in the treatment-naive group and $87 \%$ for those in the treatment-experienced group. $\mathrm{SVR}_{12}$ rates were improved to $98 \%$ for patients in the treatment-naive group and $93 \%$ for those in the treatment-experienced group when 53 was included in the regimen. In a phase III trial (UNITY 3) conducted in 217 Japanese patients infected with GT-1 HCV, SVR 12 rates of $\geq 95 \%$ were achieved in both treatment-naive $(n=152)$ and interferon-experienced $(n=65)$ cohorts after 12 weeks of therapy. The $\mathrm{SVR}_{12}$ rates were similar across the patient subgroups evaluated that included patients with cirrhosis and those aged $\geq 65$ years. These studies contributed to the approval of the fixed-dose combination of $\mathbf{1}, \mathbf{5 4}$, and 56 for marketing in Japan on December 20, 2016.

A number of clinical studies have demonstrated that co-dosing of $\mathbf{1}$ with the nucleoside-based NS5B RNA-dependent RNA polymerase inhibitor 55, with and without 53, achieves a high cure rate across HCV genotypes and patient population groups, including in those with comorbidities such as HIV-1 infection [127-129]. In a compassionate use program that reflected a real-world experience, including some subjects with advanced liver disease that would have been excluded from phase III studies, the combination of $\mathbf{1}$ and $\mathbf{5 5}$ (with and without 53) demonstrated a high 
efficacy [130]. In addition, long-term follow-up studies have demonstrated a 99\% durability for the $\mathrm{SVR}_{12}$ associated with various regimens that include $\mathbf{1}$ [131].

Daclatasvir (1) has been approved in more than 60 countries for use in combination with 54, 56, or other HCV inhibitors, including 55 [132]. A combination of all four of these agents has been evaluated in GT-1-infected patients as a drug intensification approach to shortening the duration of therapy to 4 or 6 weeks [133]. However, while the majority (96\%) of patients experienced undetectable levels of HCV RNA at the end of therapy, relapse occurred in $77 \%$ of those treated for 4 weeks and $43 \%$ of those subject to 6 weeks of treatment with quadruple therapy [133].

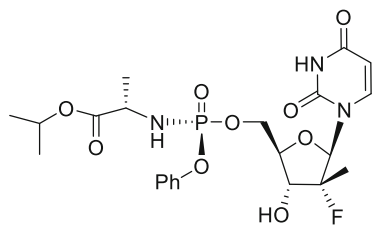

55 (sofosbuvir)

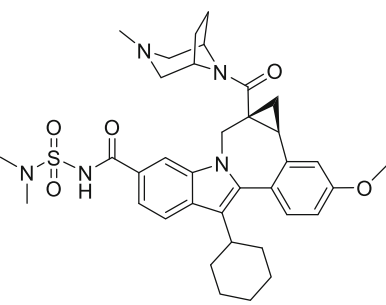

56 (beclabuvir)

\section{Conclusion}

The NS5A replication complex inhibitor class of HCV inhibitor has become established as a critical component of all of approved pan-genotypic DAA combination therapies [132]. The discovery of $\mathbf{1}$, the prototype NS5A inhibitor that is the founding member of the class, was identified only after considerable optimization of a lead discovered by phenotypic screening, a powerful approach to drug discovery that has proven to be well-suited as a means of identifying mechanistically novel antiviral agents [134-138].

\section{Compliance with Ethical Standards}

Conflict of Interest The authors are employees of Bristol-Myers Squibb and own company stock.

Ethical Approval This article does not contain any studies with human participants or animals performed by any of the authors.

\section{References}

1. Belema M, Meanwell NA (2014) Discovery of daclatasvir, a pan-genotypic hepatitis C virus NS5A replication complex inhibitor with potent clinical effect. J Med Chem 57:5057-5071

2. Belema M, Schnittman SM, Meanwell NA (2016) Case history: the discovery of the first hepatitis C virus NS5A replication complex inhibitor daclatasvir (Daklinza ${ }^{\mathrm{TM}}$ ). Med Chem Rev 51:375-397 
3. Gao M, Nettles RE, Belema M, Snyder LB, Nguyen VN, Fridell RA, Serrano-Wu MH, Langley DR, Sun J-H, O'Boyle DR II, Lemm JA, Wang C, Knipe JO, Chien C, Colonno RJ, Grasela DM, Meanwell NA, Hamann LG (2010) Chemical genetics strategy identifies an HCV NS5A inhibitor with a potent clinical effect. Nature 465:96-100

4. Belema M, Nguyen VN, Bachand C, Deon DH, Goodrich JT, James CA, Lavoie R, Lopez OD, Martel A, Romine JL, Ruediger EH, Snyder LB, St. Laurent DR, Yang F, Zhu J, Wong HS, Langley DR, Adams SP, Cantor GH, Chimalakonda A, Fura A, Johnson BM, Knipe JO, Parker DD, Santone KS, Fridell RA, Lemm JA, O'Boyle DR II, Colonno RJ, Gao M, Meanwell NA, Hamann LG (2014) Hepatitis C virus NS5A replication complex inhibitors: the discovery of daclatasvir. J Med Chem 57:2013-2032

5. Belema M, Lopez OD, Bender JA, Romine JL, Laurent DR, Langley DR, Lemm JA, O'Boyle DRII, Sun J-H, Wang C, Fridell RA, Meanwell NA (2014) The discovery and development of hepatitis C virus NS5A replication complex inhibitors. J Med Chem 57:1643-1672

6. O’Boyle DR II, Nower PT, Lemm JA, Valera L, Sun J-H, Rigat K, Colonno R, Gao M (2005) Development of a cell-based high-throughput specificity screen using a hepatitis $\mathrm{C}$ virusbovine viral diarrhea virus dual replicon assay. Antimicrob Agents Chemother 49:1346-1353

7. Lohmann V, Körner F, Koch JO, Herian U, Theilmann L, Bartenschlager R (1999) Replication of subgenomic hepatitis C virus RNAs in a hepatoma cell line. Science 285:110-113

8. Bartenschlager R (2002) Hepatitis C virus replicons: potential role for drug development. Nat Rev Drug Discov 1:911-916

9. Bartenschlager $\mathrm{R}$ (2005) The hepatitis $\mathrm{C}$ virus replicon system: from basic research to clinical application. J Hepatol 43:210-216

10. Taylor DR (2013) Evolution of cell culture systems for HCV. Antivir Ther 18:523-530

11. Lohmann V, Bartenschlager R (2014) On the history of hepatitis C virus cell culture systems. J Med Chem 57:1627-1642

12. Lemm JA, O’Boyle DR II, Liu M, Nower PT, Colonno R, Deshpande MS, Snyder LB, Martin SW, St. Laurent DR, Serrano-Wu MH, Romine JL, Meanwell NA, Gao M (2010) Identification of hepatitis C virus NS5A inhibitors. J Virol 84:482-491

13. Verma A, Saraf SK (2008) 4-Thiazolidinone - A biologically active scaffold. Eur J Med Chem 43:897-905

14. Sarkis M, Tran D-N, Dasso Lang MC, Garbay C, Braud E (2014) Convenient synthesis of 5-arylidene-2-imino-4-thiazolidinone derivatives using microwave irradiation. Synlett 25:1257-1262

15. Romine JL, St. Laurent DR, Leet JE, Martin SW, Serrano-Wu MH, Yang F, Gao M, O’Boyle DR II, Lemm JA, Sun J-H, Nower PT, Huang X, Deshpande MS, Meanwell NA, Snyder LB (2011) Inhibitors of HCV NS5A: from iminothiazolidinones to symmetrical stilbenes. ACS Med Chem Lett 2:224-229

16. Macdonald A, Harris M (2004) Hepatitis C virus NS5A: tales of a promiscuous protein. J Gen Virol 85:2485-2502

17. Pawlotsky J-M, Germanidis G (1999) The non-structural 5A protein of hepatitis C virus. J Viral Hepat 6:343-356

18. Ross-Thriepland D, Harris M (2015) Hepatitis C virus NS5A: enigmatic but still promiscuous 10 years on! J Gen Virol 96:727-738

19. De Francesco R, Neddermann P, Tomei L, Steinkühler C, Gallinari P, Folgori A (2000) Biochemical and immunologic properties of the nonstructural proteins of the hepatitis $\mathrm{C}$ virus: implications for development of antiviral agents and vaccines. Semin Liver Dis 20:69-83

20. Bukh J, Pietschmann T, Lohmann V, Krieger N, Faulk K, Engle RE, Govindarajan S, Shapiro M, St. Claire M, Bartenschlager R (2002) Mutations that permit efficient replication of hepatitis $\mathrm{C}$ virus RNA in Huh-7 cells prevent productive replication in chimpanzees. Proc Natl Acad Sci U S A 99:14416-14421

21. St Laurent DR, Gao Q, Wu D, Serrano-Wu MH (2004) Regioselective synthesis of 3-(heteroaryl)-iminothiazolindin-4-ones. Tetrahedron Lett 45:1907-1910 
22. Lemm JA, Leet JE, O’Boyle DR II, Romine JL, Huang XS, Schroeder DR, Alberts J, Cantone JL, Sun J-H, Nower PT, Martin SW, Serrano-Wu MH, Meanwell NA, Snyder LB, Gao M (2011) Discovery of potent hepatitis C virus NS5A inhibitors with dimeric structures. Antimicrob Agents Chemother 55:3795-3802

23. Leet JE, Belcastro JV, Dowling CJ, Nemeth GA, Weller HN (2015) HPLC biogram analysis: a powerful tool used for hit confirmation in early drug discovery. J Biomol Screen 20:681-687

24. Viehe HG, Janousek Z, Merenyi R, Stella L (1985) The captodative effect. Acc Chem Res $18: 148-154$

25. Ingold KU, Pratt DA (2014) Advances in radical-trapping antioxidant chemistry in the twentyfirst century: a kinetics and mechanisms perspective. Chem Rev 114:9022-9046

26. Tellinghuisen TL, Marcotrigiano J, Rice CM (2005) Structure of the zinc-binding domain of an essential component of the hepatitis C virus replicase. Nature 435:374-379

27. Love RA, Brodsky O, Hickey MJ, Wells PA, Cronin CN (2009) Crystal structure of a novel dimeric form of NS5A domain I protein from hepatitis C virus. J Virol 83:4395-4403

28. Lambert SM, Langley DR, Garnett JA, Hedgethorne K, Meanwell NA, Matthews SJ (2014) The crystal structure of NS5A domain 1 from genotype 1a reveals new clues to the mechanism of action for dimeric HCV inhibitors. Protein Sci 23:723-734

29. Lim PJ, Chatterju U, Cordek D, Sharma SD, Garcia-Rivera JA, Cameron CE, Lin K, TargettAdams P, Gallay PA (2012) Correlation between NS5A dimerization and HCV replication. J Biol Chem 287:30861-30873

30. Huang L, Hwang J, Sharma SD, Hargittai MRS, Chen Y, Arnold JJ, Raney KD, Cameron CE (2005) Hepatitis C virus nonstructural protein 5A (NS5A) is an RNA-binding protein. J Biol Chem 280:36417-36428

31. Hwang J, Huang L, Cordek DG, Vaughan R, Reynolds SL, Kihara G, Raney KD, Kao CC, Cameron CE (2010) Hepatitis C virus nonstructural protein 5A: biochemical characterization of a novel structural class of RNA-binding proteins. J Virol 84:12480-12491

32. Foster TL, Belyaeva T, Stonehouse NJ, Pearson AR, Harris M (2010) All three domains of the hepatitis $\mathrm{C}$ virus nonstructural NS5A protein contribute to RNA binding. J Virol 84:9267-9277

33. Lopez OD, Nguyen VN, St Laurent DR, Belema M, Serrano-Wu MH, Goodrich JT, Yang F, Qiu Y, Ripka AS, Nower PT, Valera L, Liu M, O’Boyle DR II, Sun J-H, Fridell RA, Lemm JA, Gao M, Good AC, Meanwell NA, Snyder LB (2013) HCV NS5A replication complex inhibitors. Part 3: discovery of potent analogs with distinct core topologies. Bioorg Med Chem Lett 23:779-784

34. St Laurent DR, Serrano-Wu MH, Belema M, Ding M, Fang H, Gao M, Goodrich JT, Krause RG, Lemm JA, Liu M, Lopez OD, Nguyen VN, Nower PT, O'Boyle DR II, Pearce BC, Romine JL, Valera L, Sun J-H, Wang Y-K, Yang F, Yang X, Meanwell NA, Snyder LB (2014) HCV NS5A replication complex inhibitors. Part 4: optimization for genotype 1a replicon inhibitory activity. J Med Chem 57:1976-1994

35. Belema M, Nguyen VN, St Laurent DR, Lopez OD, Qiu Y, Good AC, Nower PT, Valera L, O’Boyle DR II, Sun J-H, Fridell RA, Lemm JA, Gao M, Knipe JO, Meanwell NA, Snyder LB (2013) HCV NS5A replication complex inhibitors. Part 5: discovery of potent and pan-genotypic HCV NS5A replication complex inhibitors. Bioorg Med Chem Lett 23:4428-4435

36. Belema M, Nguyen VN, Romine JL, St Laurent DR, Lopez OD, Goodrich J, Nower PT, O'Boyle DR II, Lemm JA, Fridell RA, Gao M, Fang H, Krause RG, Wang Y-K, Oliver AJ, Good AC, Knipe JO, Meanwell NA, Snyder LB (2014) Hepatitis C virus NS5A replication complex inhibitors. Part 6: the discovery of a novel and highly potent biarylimidazole chemotype with inhibitory activity toward genotype $1 \mathrm{a}$ and $1 \mathrm{~b}$ replicons. J Med Chem 57:1995-2012

37. Fridell RA, Qiu D, Wang C, Valera L, Gao M (2010) Resistance analysis of the hepatitis C virus NS5A inhibitor BMS-790052 in an in vitro replicon system. Antimicrob Agents Chemother 54:3641-3650 
38. Wang C, Jia L, Huang H, Qiu D, Valera L, Huang X, Sun J-H, Nower PT, O’Boyle DR II, Gao M, Fridell RA (2012) In vitro activity of BMS-790052 on hepatitis C virus genotype 4 NS5A. Antimicrob Agents Chemother 56:1588-1590

39. Wang C, Valera L, Jia L, Kirk MJ, Gao M, Fridell RA (2013) In vitro activity of daclatasvir on hepatitis C virus genotype 3 NS5A. Antimicrob Agents Chemother 57:611-613

40. Wang C, Jia L, O'Boyle DR, Sun J-H, Rigat K, Valera L, Nower P, Huang X, Kienzle B, Roberts S, Gao M, Fridell RA (2014) Comparison of daclatasvir resistance barriers on NS5A from hepatitis $\mathrm{C}$ virus genotypes 1 to 6 : implications for cross-genotype activity. Antimicrob Agents Chemother 58:5155-5163

41. Wakenhut F, Tran TD, Pickford C, Shaw S, Westby M, Smith-Burchnell C, Watson L, Paradowski M, Milbank J, Stonehouse D, Cheung K, Wybrow R, Daverio F, Crook S, Statham K, Leese D, Stead D, Adam F, Hay D, Roberts LR, Chiva J-Y, Nichols C, David C, Blakemore D, Goetz GH, Che Y, Gardner I, Dayal S, Pike A, Webster R, Pryde DC (2014) The discovery of potent nonstructural protein 5A (NS5A) inhibitors with a unique resistance profile - part 2. ChemMedChem 9:1387-1396

42. Szabo G (2006) Hepatitis C virus NS5A protein - a master regulator? Gastroenterology 130:996-999

43. Najarro P, Mathews N, Cockerill S (2006) NS5A inhibitors. In: Tan S-L (ed) Hepatitis C viruses. Horizon Bioscience, Wymondham, pp 271-292

44. Schmitz U, Tan S-L (2008) NS5A - from obscurity to new target for HCV therapy. Recent Pat Antiinfect Drug Discov 3:77-92

45. Cordek DG, Bechtel JT, Maynard AT, Kazmierski WM, Cameron CE (2011) Targeting the NS5A protein of HCV: an emerging option. Drugs Future 36:691-711

46. Belda O, Targett-Adams P (2012) Small molecule inhibitors of the hepatitis C virus-encoded NS5A protein. Virus Res 170:1-14

47. Debes JD, Smith CI (2012) NS5A: a new target for antiviral drugs in the treatment of hepatitis C virus infection. Hepatology 56:797-799

48. Gao M, O’Boyle DR II, Roberts S (2016) HCV NS5A replication complex inhibitors. Curr Opin Pharmacol 30:151-157

49. Guedj J, Dahari H, Rong L, Sansone ND, Nettles RE, Cotler SJ, Layden TJ, Uprichard SL, Perelson AS (2013) Modeling shows that the NS5A inhibitor daclatasvir has two modes of action and yields a shorter estimate of the hepatitis C virus half-life. Proc Natl Acad Sci U S A 110:3991-3996

50. McGivern DR, Masaki T, Williford S, Ingravallo P, Feng Z, Lahser F, Asante-Appiah E, Neddermann P, De Francesco R, Howe AY, Lemon SM (2014) Kinetic analyses reveal potent and early blockade of hepatitis C virus assembly by NS5A inhibitors. Gastroenterology 147:453-462

51. Nettles RE, Gao M, Bifano M, Chung E, Persson A, Marbury TC, Goldwater R, DeMicco MP, Rodriguez-Torres M, Vutikullird A, Fuentes E, Lawitz E, Lopez-Talavera JC, Grasela DM (2011) Multiple ascending dose study of BMS-790052, a nonstructural protein 5A replication complex inhibitor, in patients infected with hepatitis C virus genotype 1. Hepatology 54:1956-1965

52. Tellinghuisen TL, Rice CM (2002) Interaction between hepatitis C virus and host cell factors. Curr Opin Microbiol 5:419-427

53. Kwofie SK, Schaefer U, Sundararajan VS, Bajic VB, Christoffels A (2011) HCVpro: hepatitis $\mathrm{C}$ virus protein interaction database. Infect Genet Evol 11:1971-1977

54. Tripathi LP, Kambara H, Chen Y-A, Nishimura Y, Moriishi K, Okamoto T, Morita E, Abe T, Mori T, Matsuura Y, Mizuguchi K (2013) Understanding the biological context of NS5A-host interactions in HCV infection: a network-based approach. J Proteome Res 12:2537-2551

55. Upadhyay A, Dixit U, Manvar D, Chaturvedi N, Pandey VN (2013) Affinity capture and identification of host cell factors associated with hepatitis $C$ virus (+) strand subgenomic RNA. Mol Cell Proteomics 12:1539-1552 
56. Dolan PT, Zhang C, Khadka S, Arumugaswami V, Vangeloff AD, Heaton NS, Sahasrabudhe S, Randall G, Sun R, LaCount DJ (2013) Identification and comparative analysis of hepatitis $C$ virus-host cell protein interactions. Mol Biosyst 9:3199-3209

57. Colpitts CC, Lupberger J, Doerig C, Baumert TF (2015) Host cell kinases and the hepatitis C virus lifecycle. Biochim Biophys Acta 1854(10 Part B):1657-1662

58. Ascher DB, Wielens J, Nero TL, Doughty L, Morton CJ, Parker MW (2014) Potent hepatitis C inhibitors bind directly to NS5A and reduce its affinity for RNA. Nat Sci Rep. https://doi.org/ 10.1038/rep04765

59. Kwon HJ, Xing W, Chan K, Niedziela-Majka A, Brendza KM, Kirschberg T, Kato D, Link JO, Cheng G, Liu X, Sakowicz R (2015) Direct binding of ledipasvir to HCV NS5A: mechanism of resistance to an HCV antiviral agent. PLoS One. https://doi.org/10.1371/ journal.pone.0122844

60. Sun J-H, O'Boyle DR II, Fridell RA, Langley DR, Wang C, Roberts SB, Nower P, Johnson BM, Moulin F, Nophsker MJ, Wang Y-K, Liu M, Rigat K, Tu Y, Hewawasam P, Kadow J, Meanwell NA, Cockett M, Lemm JA, Kramer M, Belema M, Gao M (2015) Resensitizing daclatasvir-resistance hepatitis $\mathrm{C}$ variants by allosteric modulation of NS5A. Nature 527:245-248

61. O’Boyle DR II, Nower PT, Gao M, Fridell R, Wang C, Hewawasam P, Lopez O, Tu Y, Meanwell NA, Belema M, Roberts SB, Cockett M, Sun J-H (2016) Synergistic activity of combined NS5A inhibitors. Antimicrob Agents Chemother 60:1573-1583

62. Nettles JH, Stanton RA, Broyde J, Amblard F, Zhang H, Zhou L, Shi J, McBrayer TR, Whitaker T, Coats SJ, Kohler JJ, Schinazi RF (2014) Asymmetric binding to NS5A by daclatasvir (BMS-790052) and analogs suggests two novel modes of HCV inhibition. J Med Chem 57:10031-10043

63. Issur M, Goette M (2014) Resistance patterns associated with HCV NS5A inhibitors provide limited insight into drug binding. Viruses 6:4227-4241

64. Barakat KH, Anwar-Mohamed A, Tuszynski JA, Robins MJ, Tyrrell DL, Houghton M (2015) A refined model of the $\mathrm{HCV}$ NS5A protein bound to daclatasvir explains drug-resistant mutations and activity against divergent genotypes. J Chem Inf Model 55:362-373

65. Ahmed M, Pal A, Houghton M, Barakat K (2016) A comprehensive computational analysis for the binding modes of hepatitis $\mathrm{C}$ virus NS5A inhibitors: the question of symmetry. ACS Infect Dis 2:872-881

66. Badillo A, Receveur-Brechot V, Sarrazin S, Cantrelle FX, Delolme F, Fogeron M-L, Molle J, Montserret R, Bockmann A, Bartenschlager R, Lohmann V, Lippens G, Ricard-Blum S, Hanoulle X, Penin F (2017) Overall structural model of NS5A protein from hepatitis C virus and modulation by mutations conferring resistance of virus replication to cyclosporin A. Biochemistry 56:3029-3048

67. Ahmed A, Felmlee DJ (2015) Mechanisms of hepatitis C viral resistance to direct acting antivirals. Viruses 7:6716-6729

68. Appel N, Schaller T, Penin F, Bartenschlager R (2006) From structure to function: new insights into hepatitis C virus RNA replication. J Biol Chem 281:9833-9836

69. Moon SL, Barnhart MD, Wilusz J (2012) Inhibition and avoidance of mRNA degradation by RNA viruses. Curr Opin Microbiol 15:500-505

70. Molleston JM, Cherry S (2017) Attacked from all sides: RNA decay in antiviral defense. Viruses 9:2. https://doi.org/10.3390/v9010002

71. Targett-Adams P, Graham EJ, Middleton J, Palmer A, Shaw SM, Lavender H, Brain P, Tran TD, Jones LH, Wakenhut F, Stammen B, Pryde D, Pickford C, Westby M (2011) Small molecules targeting hepatitis $\mathrm{C}$ virus-encoded NS5A cause subcellular redistribution of their target: insights into compound modes of action. J Virol 85:6353-6368

72. Qiu D, Lemm JA, O’Boyle DR II, Sun JH, Nower P, Nguyen V, Hamann LG, Snyder LB, Deon DH, Ruediger E, Meanwell NA, Belema M, Gao M, Fridell RA (2011) The effect of NS5A inhibitors on NS5A phosphorylation, polyprotein processing and localization. J Gen Virol 92:2502-2511 
73. Berger C, Romero-Brey I, Radujkovic D, Terreux R, Zayas M, Paul D, Harak C, Hoppe S, Gao M, Penin F, Lohmann V, Bartenschlager R (2014) Daclatasvir-like inhibitors of NS5A block early biogenesis of hepatitis $\mathrm{C}$ virus-induced membranous replication factories, independent of RNA replication. Gastroenterology 147:1094-1105

74. Boson B, Denolly S, Turlure F, Chamot C, Dreuz M, Cosset F-L (2017) Daclatasvir prevents hepatitis $\mathrm{C}$ virus infectivity by blocking transfer of the viral genome to assembly sites. Gastroenterology 152:895-907

75. Lee C, Ma H, Hang JQ, Leveque V, Sklan EH, Elazar M, Klumpp K, Glenn JS (2011) The hepatitis C virus NS5A inhibitor (BMS-790052) alters the subcellular localization of the NS5A non-structural viral protein. Virology 414:10-18

76. Chatterji U, Bobardt M, Tai A, Wood M, Gallay PA (2015) Cyclophilin and NS5A inhibitors, but not other anti-hepatitis $\mathrm{C}$ virus (HCV) agents, preclude $\mathrm{HCV}$-mediated formation of double-membrane-vesicle viral factories. Antimicrob Agents Chemother 59:2496-2507

77. Jiang H, Zeng J, Li W, Bifano M, Gu H, Titsch C, Easter J, Burrell R, Kandoussi H, Aubry A-F, Arnold ME (2012) Practical and efficient strategy for evaluating oral absolute bioavailability with an intravenous microdose of a stable isotopically-labeled drug using a selected reaction monitoring mass spectrometry assay. Anal Chem 84:10031-10037

78. McCormack PL (2015) Daclatasvir: a review of its use in adult patients with chronic hepatitis $\mathrm{C}$ virus infection. Drugs 75:515-524

79. Gandhi Y, Eley T, Fura A, Li W, Bertz RJ, Garimella T (2018) Daclatasvir: a review of preclinical and clinical pharmacokinetics. Clin Pharmacokinet 57:911-928. https://doi.org/10. 1007/s40262-017-0624-3

80. Keating GM (2016) Daclatasvir: a review in chronic hepatitis C. Drugs 76:1381-1391

81. Powdrill MH, Tchesnokov EP, Kozak RA, Russell RS, Martin R, Svarovskaia ES, Mo H, Kouyos RD, Götte M (2011) Contribution of a mutational bias in hepatitis C virus replication to the genetic barrier in the development of drug resistance. Proc Natl Acad Sci U S A 108:20509-20513

82. Wyles DL (2013) Antiviral resistance and the future landscape of hepatitis C virus infection therapy. J Infect Dis 207(S1):S33-S39

83. Wyles DL, Gutierrez JA (2014) Importance of HCV genotype 1 subtypes for drug resistance and response to therapy. J Viral Hepat 21:229-240

84. Fridell RA, Wang C, Sun J-H, O’Boyle DR II, Nower P, Valera L, Qiu D, Roberts S, Huang X, Kienzle B, Bifano M, Nettles RE, Gao M (2011) Genotypic and phenotypic analysis of variants resistant to hepatitis $\mathrm{C}$ virus nonstructural protein $5 \mathrm{~A}$ replication complex inhibitor BMS-790052 in humans: in vitro and in vivo correlations. Hepatology 54:1924-1935

85. Wang C, Huang H, Valera L, Sun J-H, O’Boyle DR II, Nower PT, Jia L, Qiu D, Huang X, Altaf A, Gao M, Fridell RA (2012) Hepatitis C virus RNA elimination and development of resistance in replicon cells treated with BMS-790052. Antimicrob Agents Chemother 56:1350-1358

86. Neumann AU, Lam NP, Dahari H, Gretch DR, Wiley TE, Layden TJ, Perelson AS (1998) Hepatitis $\mathrm{C}$ viral dynamics in vivo and the antiviral efficacy of interferon- $\alpha$ therapy. Science 282:103-107

87. Perelson AS, Herrmann E, Micol F, Zeuzem S (2005) New kinetic models for the hepatitis C virus. Hepatology 42:749-754

88. Shudo E, Ribeiro RM, Perelson AS (2009) Modeling HCV kinetics under therapy using PK and PD information. Expert Opin Drug Metab Toxicol 5:321-332

89. Rong L, Perelson AS (2010) Treatment of hepatitis C virus infection with interferon and small molecule direct antivirals: viral kinetics and modeling. Crit Rev Immunol 30:131-148

90. Ribeiro RM, Li H, Wang S, Stoddard MB, Learn GH, Korber BT, Bhattacharya T, Guedj J, Parrish EH, Hahn BH, Shaw GM, Perelson AS (2012) Quantifying the diversification of hepatitis $\mathrm{C}$ virus (HCV) during primary infection: estimates of the in vivo mutation rate. PLoS Pathog 8(8):e1002881. https://doi.org/10.1371/journal.ppat.1002881 
91. Chatterjee A, Guedj J, Perelson AS (2012) Mathematical modeling of HCV infection: what can it teach us in the era of direct-acting antiviral agents? Antivir Ther 17:1171-1182

92. Hézode C, Hirschfield GM, Ghesquiere W, Sievert W, Rodriguez-Torres M, Shafran SD, Thuluvath PJ, Tatum HA, Waked I, Esmat GE, Lawitz EJ, Rustgi VK, Pol S, Weis N, Pockros PJ, Bourlière M, Serfaty L, Vierling JM, Fried MW, Weiland O, Brunetto MR, Everson GT, Zeuzem S, Kwo PY, Sulkowski M, Bräu N, Hernandez D, McPhee F, Wind-Rotolo M, Liu Z, Noviello S, Hughes EA, Yin PD, Schnittman S (2015) Daclatasvir plus peginterferon alfa and ribavirin for treatment-naive chronic hepatitis $\mathrm{C}$ genotype 1 or 4 infection: a randomised study. Gut 64:948-956

93. Dore GJ, Lawitz E, Hézode C, Shafran SD, Ramji A, Tatum HA, Taliani G, Tran A, Brunetto MR, Zaltron S, Strasser SI, Weis N, Ghesquiere W, Lee SS, Larrey D, Pol S, Harley H, George J, Fung SK, de Lédinghen V, Hagens P, McPhee F, Hernandez D, Cohen D, Cooney E, Noviello S, Hughes E (2015) Daclatasvir plus peginterferon and ribavirin is noninferior to peginterferon and ribavirin alone, and reduces the duration of treatment for HCV genotype 2 or 3 infection. Gastroenterology 148:355-366

94. Sulkowski MS, Fessel WJ, Lazzarin A, Berenguer J, Zakharova N, Cheinquer H, Cote P, Dieterich D, Gadano A, Matthews G, Molina J-M, Moreno C, Pineda JA, Pulido F, Rivero A, Rockstroh J, Hernandez D, McPhee F, Eley T, Mendez P, Liu Z, Hughes E, Noviello S, Ackerman P (2017) Efficacy and safety of daclatasvir plus pegylated-interferon alfa 2a and ribavirin in previously untreated HCV subjects coinfected with HIV and HCV genotype-1: a phase III, open-label study. Hepatol Int 11:188-198

95. Suzuki F, Toyota J, Ikeda K, Chayama K, Mochida S, Hayashi N, Ishikawa H, Miyagoshi H, Hu W, McPhee F, Hughes EA, Kumada H (2014) A randomized trial of daclatasvir with peginterferon alfa-2b and ribavirin for HCV genotype 1 infection. Antivir Ther 19:491-499

96. Izumi N, Yokosuka O, Kawada N, Osaki Y, Yamamoto K, Sata M, Ishikawa H, Ueki T, Hu W, McPhee F, Hughes EA, Kumada H (2014) Daclatasvir combined with peginterferon alfa-2a and ribavirin in Japanese patients infected with hepatitis $\mathrm{C}$ genotype 1. Antivir Ther 19:501-510

97. Scola PM, Sun L-Q, Wang AX, Chen J, Sin N, Venables BL, Sit S-Y, Chen Y, Cocuzza A, Bilder DM, D'Andrea SV, Zheng B, Hewawasam P, Tu Y, Friborg J, Falk P, Hernandez D, Levine S, Chen C, Yu F, Sheaffer AK, Zhai G, Barry D, Knipe JO, Han Y-H, Schartman R, Donoso M, Mosure K, Sinz MW, Zvyaga T, Good AC, Rajamani R, Kish K, Tredup J, Klei HE, Gao Q, Mueller L, Colonno RJ, Grasela DM, Adams SP, Loy J, Levesque PC, Sun H, Shi H, Sun L, Warner W, Li D, Zhu J, Meanwell NA, McPhee F (2015) The discovery of asunaprevir (BMS-650032), an orally efficacious NS3 protease inhibitor for the treatment of hepatitis C virus infection. J Med Chem 57:1730-1752

98. McPhee F, Sheaffer AK, Friborg J, Hernandez D, Falk P, Zhai G, Levine S, Chaniewski S, Yu F, Barry D, Chen C, Lee MS, Mosure K, Sun L-Q, Sinz M, Meanwell NA, Colonno RJ, Knipe J, Scola P (2012) Preclinical profile and characterization of the hepatitis C virus NS3 protease inhibitor asunaprevir (BMS-650032). Antimicrob Agents Chemother 56:5387-5396

99. Lok AS, Gardiner DF, Lawitz E, Martorell C, Everson GT, Ghalib R, Reindollar R, Rustgi V, McPhee F, Wind-Rotolo M, Persson A, Zhu K, Dimitrova DI, Eley T, Guo T, Grasela DM, Pasquinelli C (2012) Preliminary study of two antiviral agents for hepatitis C genotype 1. N Engl J Med 366:216-224

100. Chung RT (2012) A watershed moment in the treatment of hepatitis C. N Engl J Med 366:273-275

101. McPhee F, Friborg J, Levine S, Chen C, Falk P, Yu F, Hernandez D, Lee MS, Chaniewski S, Sheaffer AK, Pasquinelli C (2012) Resistance analysis of the hepatitis C virus NS3 protease inhibitor asunaprevir. Antimicrob Agents Chemother 56:3670-3681

102. Lok AS, Gardiner DF, Hézode C, Lawitz EJ, Bourlière M, Everson GT, Marcellin P, Rodriguez-Torres M, Pol S, Serfaty L, Eley T, Huang S-P, Li J, Wind-Rotolo M, Yu F, McPhee F, Grasela DM, Pasquinelli C (2014) Randomized trial of daclatasvir and asunaprevir 
with or without PegIFN/RBV for hepatitis C virus genotype 1 null responders. J Hepatol 60:490-499

103. Toyoda H, Kumada T, Takaguchi K, Shimada N, Tanaka J (2014) Changes in hepatitis C virus genotype distribution in Japan. Epidemiol Infect 142:2624-2628

104. Chung H, Ueda T, Kudo M (2010) Changing trends in hepatitis C infection over the past 50 years in Japan. Intervirology 53:39-43

105. Chayama K, Takahashi S, Toyota J, Karino Y, Ikeda K, Ishikawa H, Watanabe H, McPhee F, Hughes E, Kumada H (2012) Dual therapy with the nonstructural protein 5A inhibitor, daclatasvir, and the nonstructural protein 3 protease inhibitor, asunaprevir, in hepatitis $\mathrm{C}$ virus genotype 1b-infected null responders. Hepatology 55:742-748

106. Wang HL, Lu X, Yang X, Xu N (2017) Effectiveness and safety of daclatasvir plus asunaprevir for hepatitis $\mathrm{C}$ virus genotype 1b: systematic review and meta-analysis. J Gastroenterol Hepatol 32:45-52

107. Poole RM (2014) Daclatasvir + asunaprevir: first global approval. Drugs 74:1559-1571

108. Karino Y, Toyota J, Ikeda K, Suzuki F, Chayama K, Kawakami Y, Ishikawa H, Watanabe H, Hernandez D, Yu F, McPhee F, Kumada H (2013) Characterization of virologic escape in hepatitis $\mathrm{C}$ virus genotype $1 \mathrm{~b}$ patients treated with the direct acting antivirals daclatasvir and asunaprevir. J Hepatol 58:646-654

109. Suzuki Y, Ikeda K, Suzuki F, Toyota J, Karino Y, Chayama K, Kawakami Y, Ishikawa H, Watanabe J, Hu W, Eley T, McPhee F, Hughes E, Kumada H (2013) Dual oral therapy with daclatasvir and asunaprevir for patients with $\mathrm{HCV}$ genotype $1 \mathrm{~b}$ infection and limited treatment options. J Hepatol 58:655-662

110. Kumada H, Suzuki Y, Ikeda K, Toyota J, Karino Y, Chayama K, Kawakami Y, Ido A, Yamamoto K, Takaguchi K, Izumi N, Koike K, Takehara T, Kawada N, Sata M, Miyagoshi H, Eley T, McPhee F, Damokosh A, Ishikawa H, Hughes E (2014) Daclatasvir plus asunaprevir for chronic HCV genotype 1b infection. Hepatology 59:2083-2091

111. McPhee F, Suzuki Y, Toyota J, Karino Y, Chayama K, Kawakami Y, Yu ML, Ahn SH, Ishikawa H, Bhore R, Zhou N, Hernandez D, Mendez P, Kumada H (2015) High sustained virologic response to daclatasvir plus asunaprevir in elderly and cirrhotic patients with hepatitis C virus genotype $1 \mathrm{~b}$ without baseline NS5A polymorphisms. Adv Ther 32:637-649

112. Kanda T, Yasui S, Nakamura M, Suzuki E, Arai M, Haga Y, Sasaki R, Wu S, Nakamoto S, Imazeki F, Yokosuka O (2016) Daclatasvir plus asunaprevir treatment for real-world HCV genotype 1-infected patients in Japan. Int J Med Sci 13:418-423

113. Kumada H, Suzuki F, Suzuki Y, Toyota J, Karino Y, Chayama K, Kawakami Y, Fujiyama S, Ito T, Itoh Y, Tamura E, Ueki T, Ishikawa H, Hu W, McPhee F, Linaberry M, Hughes E (2016) Randomized comparison of daclatasvir+asunaprevir versus telaprevir+peginterferon/ ribavirin in Japanese hepatitis C virus patients. J Gastroenterol Hepatol 31:14-22

114. Akuta N, Sezaki H, Suzuki F, Kawamura Y, Hosaka T, Kobayashi M, Kobayashi M, Saitoh S, Suzuki Y, Arase Y, Ikeda K, Kumada H (2017) Favorable efficacy of daclatasvir plus asunaprevir in treatment of elderly Japanese patients infected with HCV genotype 1b aged 70 and older. J Med Virol 89:91-98

115. Toyoda H, Kumada T, Tada T, Shimada N, Takaguchi K, Senoh T, Tsuji K, Tachi Y, Hiraoka A, Ishikawa T, Shima T, Okanoue T (2017) Efficacy and tolerability of an IFN-free regimen with DCV/ASV for elderly patients infected with HCV genotype 1B. J Hepatol 66:521-527

116. Sezaki H, Suzuki F, Hosaka T, Akuta N, Fujiyama S, Kawamura Y, Kobayashi M, Suzuki Y, Saitoh S, Arase Y, Ikeda K, Kobayashi M, Kumada H (2017) The efficacy and safety of dual oral therapy with daclatasvir and asunaprevir for genotype $1 \mathrm{~b}$ in Japanese real-life settings. Liver Int 37:1325-1333

117. Hayes CN, Imamura M, Chayama K (2017) The practical management of chronic hepatitis C infection in Japan - dual therapy of daclatasvir + asunaprevir. Expert Rev Gastroenterol Hepatol 11:103-113 
118. Adler H, Lambert JS (2014) Daclatasvir for the treatment of hepatitis C virus infection. Expert Rev Gastroenterol Hepatol 8:725-738

119. Gamal N, Gitto S, Andreone P (2016) Efficacy and safety of daclatasvir in hepatitis C: an overview. J Clin Transl Hepatol 4:336-344

120. Gentles RG, Ding M, Bender JA, Bergstrom CP, Grant-Young K, Hewawasam P, Hudyma T, Martin S, Nickel A, Regueiro-Ren A, Tu Y, Yang Z, Yeung K-S, Zheng X, Chao S, Sun J-H, Beno BR, Camac DM, Chang C-H, Gao M, Morin PE, Sheriff S, Tredup J, Wan J, Witmer MR, Xie D, Hanumegowda U, Knipe J, Mosure K, Santone KS, Parker DD, Zhuo X, Lemm J, Liu M, Pelosi L, Rigat K, Voss S, Wang Y, Wang Y-K, Colonno RJ, Gao M, Roberts SB, Gao Q, Ng A, Meanwell NA, Kadow JF (2014) Discovery and preclinical characterization of the cyclopropylindolobenzazepine BMS-791325, a potent allosteric inhibitor of the hepatitis C virus NS5B polymerase. J Med Chem 57:1855-1879

121. Poordad F, Sievert W, Mollison L, Bennett M, Tse E, Brau N, Levin J, Sepe T, Lee SS, Angus P, Conway B, Pol S, Boyer N, Bronowicki J-P, Jacobson I, Muir AJ, Reddy KR, Tam E, Ortiz-Lasanta G, de Ledinghen V, Sulkowski M, Boparai N, McPhee F, Hughes E, Swenson ES, Yin PD, UNITY-1 Study Group (2013) Fixed-dose combination therapy with daclatasvir, asunaprevir, and beclabuvir for noncirrhotic patients with HCV genotype 1 infection. J Am Med Assoc 313:1728-1735

122. Muir AJ, Poordad F, Lalezari J, Everson G, Dore GJ, Herring R, Sheikh A, Kwo P, Hézode C, Pockros PJ, Tran A, Yozviak J, Reau N, Ramji A, Stuart K, Thompson AJ, Vierling J, Freilich B, Cooper J, Ghesquiere W, Yang R, McPhee F, Hughes EA, Swenson ES, Yin PD (2015) Daclatasvir in combination with asunaprevir and beclabuvir for hepatitis $C$ virus genotype 1 infection with compensated cirrhosis. J Am Med Assoc 313:1736-1744

123. Hassanein T, Sims KD, Bennett M, Gitlin N, Lawitz E, Nguyen T, Webster L, Younossi Z, Schwartz H, Thuluvath PJ, Zhou H, Rege B, McPhee F, Zhou N, Wind-Rotolo M, Chung E, Griffies A, Grasela DM, Gardiner DF (2015) A randomized trial of daclatasvir in combination with asunaprevir and beclabuvir in patients with chronic hepatitis $C$ virus genotype 4 infection. J Hepatol 62:1204-1206

124. Toyota J, Karino Y, Suzuki F, Ikeda F, Ido A, Tanaka K, Takaguchi K, Naganuma A, Tomita E, Chayama K, Fujiyama S, Inada Y, Yoshiji H, Watanabe H, Ishikawa H, Hu W, McPhee F, Linaberry M, Yin PD, Swenson ES, Kumada H (2017) Daclatasvir/asunaprevir/ beclabuvir fixed-dose combination in Japanese patients with HCV genotype 1 infection. J Gastroenterol 52:385-395

125. Kao JH, Yu ML, Peng CY, Heo J, Chu CJ, Chang TT, Lee YJ, Hu TH, Yoon KT, Paik SW, Lim YS, Ahn SH, Isakov V, McPhee F, Hu W, Swenson ES, Yin PD, Treitel M (2017) Daclatasvir/asunaprevir/beclabuvir, all-oral, fixed-dose combination for patients with chronic hepatitis C virus genotype 1. J Gastroenterol Hepatol 32:1998-2005

126. Ahmed AM, Doheim MF, Mattar OM, Sherif NA, Truong DH, Le Hoa PT, Hirayama K, Huy NT (2018) Beclabuvir in combination with asunaprevir and daclatasvir for hepatitis $\mathrm{C}$ virus genotype 1 infection: a systematic review and meta-analysis. J Med Virol 90:907-918. https:// doi.org/10.1002/jmv. 24947

127. Poordad F, Schiff ER, Vierling JM, Landis C, Fontana RJ, Yang R, McPhee F, Hughes EA, Noviello S, Swenson ES (2016) Daclatasvir with sofosbuvir and ribavirin for hepatitis C virus infection with advanced cirrhosis or post-liver transplantation recurrence. Hepatology 63:1493-1505

128. Wyles DL, Ruane PJ, Sulkowski MS, Dieterich D, Luetkemeyer A, Morgan TR, Sherman KE, Dretler R, Fishbein D, Gathe JC, Henn S, Hinestrosa F, Huynh C, McDonald C, Mills A, Overton ET, Ramgopal M, Rashbaum B, Ray G, Scarsella A, Yozviak J, Mcphee F, Liu Z, Hughes E, Yin PD, Noviello S, Ackerman P (2015) Daclatasvir plus sofosbuvir for HCV in patients coinfected with HIV-1. N Engl J Med 373:714-725

129. Nelson DR, Cooper JN, Lalezari JP, Lawitz E, Pockros PJ, Gitlin N, Freilicj BF, Younes ZH, Harlan W, Ghalib R, Oguchi G, Thuluvath PJ, Ortiz-Lasanta G, Rabinovitz M, Berstein D, Bennett M, Hawkins T, Ravendhran N, Sheikh A, Varunok P, Kowdley KV, Hennicken D, 
McPhee F, Rana K, Hughes EA (2015) All-oral 12-week treatment with daclatasvir plus sofosbuvir in patients with hepatitis C virus genotype 3 infection: ALLY-3 phase III study. Hepatology 61:1127-1135

130. Welzel TM, Petersen J, Herzer K, Ferenci P, Gschwantler M, Wedemeyer H, Berg T, Spengler U, Weiland O, van der Valk M, Rockstroh J, Peck-Radosavljevic M, Zhao Y, Jumenez-Exposito MJ, Zeuzem S (2016) Daclatasvir plus sofobuvir, with and without ribavirin, achieved high sustained virological response rates in patients with $\mathrm{HCV}$ infection and advanced liver disease in a real-world cohort. Gut 65:1861-1870

131. Reddy KP, Pol S, Thuluvath PJ, Kumada H, Toyota J, Chayama K, Levin J, Lawitz EJ, Gadano A, Ghesquiere W, Gerken G, Brunetto MR, Peng C-Y, Silva M, Strasser SI, Heo J, McPhee F, Liu Z, Yang R, Linaberry M, Noviello S (2018) Long-term follow-up of clinical trial patients treated for chronic HCV infection with daclatasvir-based regimens. Liver Int 38:821-833. https://doi.org/10.1111/liv.13596

132. Li G, De Clercq E (2017) Current therapy for chronic hepatitis C: the role of direct-acting antivirals. Antivir Res 142:83-122

133. Sulkowski MS, Flamm S, Kayali Z, Lawitz EJ, Kwo P, McPhee F, Torbeyns A, Hughes EA, Swenson ES, Yin PD, Linaberry M (2017) Short-duration treatment for chronic hepatitis C virus with daclatasvir, asunaprevir, beclabuvir and sofosbuvir (FOURward study). Liver Int 37:836-842

134. Gentile I, Borgia F, Coppola N, Buonomo AR, Castaldo G, Borgia G (2014) Daclatasvir: the first of a new class of drugs targeted against hepatitis C virus NS5A. Curr Med Chem 21:1391-1404

135. Swinney DC, Anthony J (2011) How were new medicines discovered? Nat Rev Drug Discov 10:507-519

136. Macarron R, Banks MN, Bojanic D, Burns DJ, Cirovic DA, Garyantes T, Green DVS, Hertzberg RP, Janzen WP, Paslay JW, Schopfer U, Sittampalam GS (2011) Impact of highthroughput screening on biomedical research. Nat Rev Drug Discov 10:189-195

137. Green N, Ott RD, Isaacs RJ, Fang H (2008) Cell-based assays to identify inhibitors of viral disease. Expert Opin Drug Discov 3:671-676

138. Keller TH, Shi P-Y, Wang Q-Y (2011) Anti-infectives: can cellular screening deliver? Curr Opin Chem Biol 15:529-533 